\title{
FILIAÇÃO INTENSIVA E ALIANÇA DEMONÍACA
}

\author{
EDUARDO VIVEIROS DE CASTRO
}

\section{RESUMO}

Este artigo sugere duas direções para o aprofundamento de um diálogo entre Deleuze e a antropologia. Na primeira parte, traça paralelos entre conceitos deleuzianos e temas analíticos influentes na antropologia de hoje; na segunda, examina uma incidência específica da antropologia social clássica - a teoria do parentesco - sobre a concepção deleuzo-guattariana da máquina territorial primitiva, ou semiótica pré-significante.

PALAVRAS-CHAVE: Deleuze; Guattari; antropologia social; parentesco.

\section{SUMMARY}

This article proposes an intensification of the dialogue between Deleuze and anthropology in at least two ways. In the first part, it traces proximities between deleuzian concepts and influent analytical themes for today's anthropology; in the second, examines an specific incidence of classical social anthropology - the kinship theory — on Deleuze and Guattari's conception of primitive territorial machine, or presignifier semiotics.

KEYWORDS: Deleuze; Guattari; social anthropology; kinship.

C'est en intensité qu'il faut tout interpréter G. Deleuze \& F. Guattari,L'Anti-OEdipe

I

DELEUZE E A ANTROPOLOGIA

[1] Afração da humanidade determinada pelo pronome "nossa" (apercepção cultural) é aquela que se imagina.

\footnotetext{
[2] P. Pignarre e I.Stengers.Lasorcellerie capitaliste. Pratiques de desenvôิtement. Paris: La Découverte, 2005 , pp. 49-53.
}

Para a minha geração, o nome de Gilles Deleuze evoca de pronto a mudança de orientação no pensamento que marcou os anos em torno de 1968, durante os quais alguns elementos-chave de nossa presente apercepção cultural foram inventados ${ }^{1}$. $O$ significado, as conseqüências e a própria realidade dessa mudança são objeto de uma controvérsia que ainda grassa. Para os servidores espirituais da ordem, aquelas muitas "petites mains" que trabalham pela Maioriaª , a mudança representou sobretudo algo de que foi e continua a ser preciso proteger as gerações futuras - os protetores de hoje tendo sido os protegidos de ontem e vice-versa e assim por diante - - difundindo a convicção de que o evento-68 se consumiu sem se consumar, ou seja, 
que na verdade nada aconteceu. A verdadeira revolução se fez contra o evento e foi ganha pela razão (para usarmos o eufemismo de praxe), força que firmou o Império como a máquina planetária em cujas entranhas realiza-se a união mística do Capital com a Terra - a "globalização" - e a sua transfiguração gloriosa em Noosfera - a "economia da informação", ou "capitalismo cognitivo". (Se o capital não está sempre com a razão, dir-se-ia que a razão está sempre com o capital.) Para muitos outros, ao contrário, os inservíveis que não conseguiram não escolher uma trajetória minoritária, insistindo romanticamente (para usarmos o insulto de praxe) que um outro mundo é possível, a propagação da peste neoliberal e a consolidação tecnopolítica das sociedades de controle só poderão ser enfrentadas se continuarmos capazes de conectar com os fluxos de desejo que subiram à superfície por um brilhante e fugaz momento; já lá vão quase quarenta anos. Para esses outros, o evento puro que foi 68 ainda não terminou, e ao mesmo tempo talvez nem sequer tenha começado, inscrito como parece estar em uma espécie de futuro do subjuntivo histórico. ${ }^{3}$

Gostaria de me incluir, com ou sem razão, entre esses outros. Por isso, diria a mesma coisa da influência de Deleuze e de seu parceiro Félix Guattari, autores da obra mais radicalmente consistente, do ponto de vista conceitual, e mais consistentemente radical, do ponto de vista político, produzida na filosofia da segunda metade do século $\mathrm{XX}$ : que essa influência está longe de ter atualizado todo o seu potencial. A presença dos conceitos deleuzianos (e deleuzo-guattarianos) em certas disciplinas ou campos de investigação contemporâneos é, com efeito, bem menos evidente ou direta do que se deveria esperar, manifestando-se ali antes por meio de seus efeitos sistêmicos difusos no ambiente cultural das últimas décadas. Uma disciplina em queessa presença ainda se mostra demasiado tímida é aquela que pratico, a antropologia social.

A relevância para a antropologia da obra de Deleuze e Guattari é no mínimo tão grande quanto a de pensadores como Michel Foucault ou Jacques Derrida, cujos trabalhos já foram extensivamente absorvidos (ainda que freqüentemente mal entendidos) pelo que poderíamos chamar de contracorrentes dominantes do pensamento social contemporâneo, na antropologia inclusive; contracorrentes que, note-se, não correm na França. As relações entre antropologia e filosofia se intensificaram sobremaneira no último quartel do século passado, mas o processo se desenrolou essencialmente na academia anglo-saxã, na qual a antropologia, como outras humanities, tem se mostrado muito mais aberta à "filosofia continental" que a antropologia francesa ela própria. A analítica existencial de Heidegger, a fenomenologia da corporalidade de Merleau-Ponty, a microfísica do poder de Foucault e o método da desconstrução de Derrida vieram se
[3] G. Deleuze e F. Guattari, "Mai 68 n'a pas eulieu”.In: D.Lapoujade(org.). Deux régimes de fous. Textes et entretiens 1975-1995. Paris: Minuit, 1984, pp. 214-20. Para uma reflexão de inspiração deleuziana sobre o projeto altermundialista, ver o trabalho já citado de P. Pignarre e I. Stengers, 2005 . 
[4] D. Eribon: "Este refluxo do estruturalismo foi acompanhado de um retorno às formas mais tradicionais de filosofia..."; C. Lévi-Strauss: "Os dois fenômenos estão ligados" (apud P. Maniglier, "L' humanisme interminable de Claude Lévi-Strauss". Les Temps Modernes, 609, 2000, p. 216.)

[5] F. Cusset. French theory. Foucault, Derrida, Deleuze $\&$ Cie er les mutations de la vie intelectuelle aux États-Unis. Paris: La Découverte, 2003.
[6] Doravante usaremos GD para as referências bibliográficas a Deleuze e DG para Deleuze \& Guattari. As referências citadas neste artigo provêm dos textos originais; as traduções são de minha responsabilidade, exceto quando indicado. E para suas obras LAAnti-QEdipe. Capitalisme et schizophrénie.Paris: Minuit, 1972, usaremos $A E$, e MP para Milles plateaux. Capitalisme et schizophrénie. Paris: Minuit, 1981. somar, nos anos 1980 e 1990, aos ventos continentais que já sopravam na década de 1970, responsáveis pela popularidade, na antropologia americana e britânica, de diferentes sabores do marxismo velho-europeu - uma sucessão de influências que podem ser vistas, aliás, como reações imunológicas ao estruturalismo lévi-straussiano, a ameaça continental dominante na década de 1960. Na Velha Europa, em particular na França, as relações entre antropologia e filosofia foram-se esgarçando no mesmo passo em que o estruturalismo perdia seu ímpeto paradigmático, ou foram sendo reconfiguradas em bases antes pré-que pós-estruturalistas4. O pós-estruturalismo filosófico, a "French theory" por excelências, teve pouco efeito sobre a antropologia feita naquele país, enquanto foi, ao contrário, o principal responsável pela aproximação entre as duas disciplinas nos países de língua inglesa (não sem reações violentas, é claro, da parte de boa parte - do cardinalato epistêmico nativo).

Um curioso entrecruzamento, pois: a melhor antropologia anglosaxã atual faz amplo uso da filosofia francesa oriunda de 68 , enxertando-a de modo inventivo no arraigado habitus empiriopragmatista indígena; a antropologia francesa, em troca - com as exceções de praxe, a mais notável sendo a de Bruno Latour, cuja condição de antropólogo é, talvez por isso mesmo, localmente questionada -, mostra ao contrário sinais de franca reabsorção por seu substrato geológico durkheimiano, o que não a impede (impossible n'estpasfrançais) de andar estudando propostas de casamento com diversas filiais locais da tradição analítica e logicista hegemônica no mundo anglo, que conhece uma expansão, na França de hoje, tão rápida e inexplicável como a da rede McDonald's.

A novidade da filosofia de Deleuze foi logo percebida pelas múltiplas políticas contraculturais que emergiram de 68 , pela arte experimental e pelos movimentos de minorias, em particular por algumas correntes do mais importante de todos eles, o feminismo. Não muito mais tarde, ela foi incorporada ao repertório conceitual de novos projetos estratégicos de antropologia simétrico-reflexiva, como os science studies, e foi reivindicada por algumas disquisições influentes sobre a dinâmica do capitalismo tardio. Em contrapartida, as tentativas de articulação entre a antropologia social clássica (o estudo dos sujeitos e objetos minoritários, em todos os sentidos dessas três palavras) e os conceitos deleuzianos ainda são relativamente raras, e quase sempre tímidas, ao contrário do que se poderia esperar. Afinal, o díptico Capitalismo e esquizofrenia ${ }^{6}$ apóia muitos de seus argumentos em uma vasta bibliografia sobre povos não-ocidentais, dos Guayaki aos Kachin e dos Nuer aos mongóis, desenvolvendo a partir dela teses ricas em implicações antropológicas - ricas demais, talvez, para certas constituições teóricas mais delicadas. Por outro lado, o trabalho de alguns 
dos antropólogos mais inovadores nas últimas duas décadas, como Roy Wagner, Marilyn Strathern ou Bruno Latour, mostra conexões muito sugestivas, que ainda não creio tenham sido registradas, com as idéias de Deleuze; conexões que ainda não foram, sobretudo, conectadas entre si. No caso de Wagner, elas parecem ser puramente virtuais, fruto de uma "evolução aparalela" (no sentido de Deleuze) ou uma "invenção" (no sentido de Wagner) independente; nem por isso são menos reais, ou menos surpreendentes. Em Strathern, as conexões são parciais (et pour cause) ${ }^{7}$, ou indiretas; mas a antropóloga de Cambridge compartilha com Deleuze uma teia de termos conceitualmente densos, como multiplicidade, perspectiva, dividual, fractalidade. Sob diversos aspectos, Strathern é o antropólogo mais "molecularmente" deleuziano, dentre os três citados. No caso de Latour, as conexões são atuais e explícitas, "molares", constituindo um dos alicerces da infraestrutura teórica deste pensador; ao mesmo tempo, há porções significativas da obra de Latour alheias ao espírito da filosofia deleuziana. ${ }^{8}$

Não é acidental que os três antropólogos acima estejam entre os poucos que poderiam ser rotulados de pós-estruturalistas (antes que, por exemplo, de pós-modernos) com alguma propriedade. Eles assimilaram o que havia de novo no estruturalismo e seguiram adiante,em vez de, como tantos de seus colegas, embarcar em projetos teóricos francamente retrógrados, como o pseudo-imanentismo sentimental dos mundos vividos, das moradas existenciais e das práticas incorporadas, ou a truculência macho-positivista de Teorias de Tudo, tais o sociologismo bourdivino, o cognitivismo high-tech ou a psicologia evolucionária. Da mesma forma, o pensamento de Deleuze, desde pelo menos os dois livros decisivos de 1968 e 1969, Diferença e repetição e Lógica do sentido, pode ser visto como um projeto de desterritorialização sistemática do estruturalismo, movimento de que Deleuze extraiu as intuições mais originais, para com a ajuda delas partir em outras direções 9 . Esses dois livros, com efeito, marcam ao mesmo tempo a expressão mais sofisticada do estruturalismo filosófico e sua mais ousada radicalização, sua torção teórica até um ponto de ruptura. Tal ruptura se tornará explícita com o Anti-Édipo, livro que foi um dos principais eixos de cristalização de um pós-estruturalismo em sentido próprio, isto é, um estilo de pensamento que se desenvolveu como magnificação dos aspectos mais inovadores do estruturalismo em relação ao que "vinha antes", mas também como abandono (muitas vezes barulhento) de seus aspectos mais conservadores. ${ }^{10}$

O antropólogo que decideler ou reler Deleuzee Guattari, depois de anos de imersão na literatura de sua própria disciplina, não pode deixar de experimentar uma curiosa sensação, como um déjà vu às avessas: já vi isso escrito depois... Muitas das perspectivas teóricas e técnicas descritivas que apenas recentemente, na antropologia, começaram a
[7] M. Strathern.Partial connections. Savage, Md.: Rowman and Littlefield, 1991.

[8] B. Latour já indicou a importância doAnti-Édipo para sua formação;o filosófo que lhe é mais próximo é, porém, Michel Serres, cuja obra intersecta aliás em vários pontos a de Deleuze. Wagner (que é americano)e Strathern (que é britânica), cujos trabalhos estão diretamente relacionados, são antropólogos "clássicos", especialistas na Melanésia; ambos também escreveram textos importantes sobre a tradição cultural ocidental, e Strathern publicou análises enormemente influentes das práticas de conhecimento ocidentais, em particular daquelas associadas ao parentesco. $O$ francês Latour, como se sabe, é tudo menos um antropólogo clássico, pela razão mesma que seu trabalho reproblematizou o escopo da antropologia, ao incorporar as ciências - e portanto as condições perspectivas de possibilidade da antropologia - no rol dos objetos possíveis de uma etnografia "clássica".

[9] D. Lapoujade. "Le structuralisme dissident de Deleuze". In A. Akay (org.). Gilles Deleuze için/Pour Gilles Deleuze. Istambul: Akbank Sanat, pp. 27-36.

[10] Observe-se de passagem que se não o século, como previu Foucault, é pelo menos o estruturalismo que, em reavaliações recentes, parece estar se tornando deleuziano (o que é diferente de dizer que Deleuze está-se tornando estruturalista). Assim transparece, por exemplo, no minucioso e instigante comentário dos escritos de Saussure por Maniglier (La vie énigmatiques des signes. Saussure et la naissance du structuralisme. Paris: Léo Scheer, 2006). 
[11] “Talvez esse sentimento de déjà $v u$ seja também um sentimento de se habitar uma matriz cultural..." (M. Strathern, op. cit., p. 25). O leitor poderá conferir a pregnância de tal "matriz" - mas o termo deve ser tomado como prospectivo tanto ou mais que como retrospectivo - no beloSeis propostas para o próximo milênio: Lições americanas, de Italo Calvino (São Paulo: Companhia das Letras, 2001 [1988]), cujas seis "propostas para o próximo milênio" incluem pelo menos três qualidades ou valores lógico-estéticos emblemáticas do pensamento deleuziano: “leveza", "rapidez", "multiplicidade" [...] E poderá voltar a Diferença repetição para recordar que Deleuze via seu livro como expressão de um certo espírito da época, do qual o autor pretendia extrair todas as consequências filosóficas (GD.Différence et répétition. Paris: PUF, 1968, p.1).
[12] MP, p. 123 . perder seu perfume de escândalo "fazem rizoma" poderosamente com os textos deleuzo-guattarianos de quinze ou vinte anos antes ${ }^{11}$. Para situar com precisão o valor antropológico destes textos, seria preciso descrever em detalhe a constelação de forças em que a antropologia social se vê hoje implicada, algo que ultrapassa o âmbito de minha competência. Se quisermos ser genéricos, entretanto, nãoé difícil assinalar a participação de Deleuze na sedimentação de uma certa estética conceitual contemporânea. Essa nova estética pode ser caracterizada com o auxílio do vocabulário binário do estruturalismo, até porque ela é uma resposta a esta outra estética, ou melhor,é uma reproblematização interna dela. Assim, observa-se já há algum tempo um deslocamento do foco de interesse, nas ciências humanas, para processos semióticos como a metonímia, a indicialidade e a literalidade - três modos de recusar a metáfora e a representação (a metáfora como essência da representação), de privilegiar a pragmática sobre a semântica, e de valorizar a parataxe sobre a sintaxe (a coordenação sobre a subordinação). A "virada lingüística" que, no século passado, foi o foco virtual de convergência de temperamentos, projetos e sistemas filosóficos tão diversos, parece estar começando a virar para outros lados, para longe da lingüística e, até certo ponto, da linguagem enquanto macroparadigma antropológico: as ênfases acima sugeridas mostram como as linhas de escape da linguagem como modelo foram sendo divisadas de dentro mesmo do modelo da linguagem.

Dito de outra forma, o antigo postulado da descontinuidade ontológica entre o signo e o referente, a linguagem e o mundo, que garantia a realidade da primeira e inteligibilidade do segundo e viceversa, e que serviu de fundamento e pretexto para tantas outras descontinuidades e exclusões - entre mito e filosofia, magia e ciência, primitivos e civilizados - parece estar em via de se tornar metafisicamente obsoleto;é por aqui que estamos deixando de ser, ou melhor, que estamos jamais-tendo-sido modernos. Do lado do "mundo" (um lado que não tem mais outro lado, pois que agora feito ele próprio apenas de lados), a mudança de ênfase correspondente veio privilegiar o fracionário-fractal e o diferencial em detrimento do unitário-inteiro e do combinatório, as multiplicidades planas ali onde se valorizavam as totalidades hierárquicas, a conexão transcategorial de elementos heterogêneos mais que a correspondência entre séries internamente homogêneas, a continuidade (ondulatória ou topológica) das forças antes que a descontinuidade (corpuscular ou geométrica) das formas. "Eis o que gostaríamos de dizer: um cromatismo generalizado [...]"12. A descontinuidade massiva (molar) entre as duas séries internamente homogêneas do significante e do significado, por um lado - elas mesmas em descontinuidade estrutural e a série fenomenologicamente contínua do real, por outro, desman- 
cha-se em descontinuidades moleculares ou fractais, em auto-similaridades transeriais que potenciam a diferença e a revelam como variação contínua - ou, antes, que revelam a continuidade como intrinsecamente diferencial e heterogênea (distinção entre as idéias de contínuo e de indiferenciado). Uma ontologia "plana" e uma correspondente epistemologia "simétrica"; o colapso, na verdade, da distinção entre epistemologia (linguagem) e ontologia (mundo), e a progressiva emergência de uma "ontologia prática"13, dentro da qual o conhecer não é mais um modo de representaro (des)conhecido mas de interagir com ele, isto é, um modo de criar antes que um modo de contemplar, de refletir ou de comunicar ${ }^{14}$. A tarefa do conhecimento deixa de ser a de unificar o diverso sob a representação, passando a ser a de "multiplicar o número de agências que povoam o mundo" (Latour). Os harmônicos deleuzianos são audíveis. Uma nova imagem do pensamento. Nomadologia. Multinaturalismo. ${ }^{15}$

O presente artigo pretende explorar um setor muito limitado dessa estética conceitual.A título de exemplo mais que qualquer outra coisa, ele sugere duas direções para o aprofundamento de um diálogo possível entre Deleuze e a antropologia. Nesta primeira parte, o artigo traça alguns paralelos esquemáticos entre conceitos deleuzianos e temas analíticos influentes na antropologia de hoje; na segunda, examina uma incidência específica da antropologia social clássica - a teoria do parentesco - sobre a concepção deleuzo-guattariana da máquina territorial primitiva, ou semiótica pré-significante.

\section{UMA ANTI-SOCIOLOGIA DAS MULTIPLICIDADES}

No Anti-Édipo (1972), primeiro livro de Capitalismo e esquizofrenia, Deleuze e Guattari derrubam o pilar central do templo da psicanálise, a saber, a concepção reacionária do desejo como falta, substituindo-o por uma teoria das máquinas desejantes enquanto pura produtividade positiva que deve ser codificada pelo socius, a máquina de produção social. Essa teoria passa por um amplo panorama da história universal, pintado no capítulo central do livro em um estilo provocativamente arcaizante, que talvez assuste de início o leitor antropólogo. Não só os autores empregam a seqüência tradicional selvageria-barbárie-civilização na função de moldura expositiva, como as abundantes referências etnográficas são tratadas de um modo que se poderia chamar de "comparação descontrolada" ${ }^{16}$. Mas o mesmo leitor não demorará a se dar conta de que o topos dos três estágios é ali submetido a uma interpretação que pode ser tudo, menos tradicional, e que a impressão de descontrole comparativo deriva do fato de os controles usados pelos autores serem outros que os usuais - de tipo "diferenciante" antes que "coletivizante", nos termos de Roy Wagner ${ }^{17}$. Anti-
[13] M. DeLanda.Intensive science and virtual philosophy. Londres: Continuum, 2002; B. Latour. Nous n'avons jamais été modernes. Paris: La Découverte, 1991; C. B.Jensen. "Anonhumanist disposition: on performativity, practical ontology, and intervention". Configurations, 12, pp. 229-61, 2004.

[14] DG. Qu'est-ce que la philosophie? Paris: Minuit, 1991.

[15] A noção de uma ontologia plana remete à "univocidade do ser", tese medieval reciclada por Deleuze: "a univocidade é a síntese imediata do múltiplo.Oumnãose diz senão do múltiplo, ao invés de que este último se subordine ao um como ao gênero superior e comum capaz deenglobá-lo" (F.Zourabichvili. Le vocabulaire de Deleuze. Paris: Ellipses, 2003, p. 82). O comentador prossegue: "O corolário desta síntese imediata do múltiplo é o desdobrar de todas as coisas sobre um plano comum de igualdade: 'comum' aqui não tem o sentido de uma identidade genérica, mas de uma comunicação transversal e sem hierarquia entre seres que simplesmente diferem. A medida (ou hierarquia) muda igualmente de sentido: ela não é mais a medida externa dos seres em relação a um padrão, mas a medida interior a cada ser em sua relação com seus próprios limites" (idem, pp. 82-3). A idéia de ontologia plana é extensamente comentada em DeLanda (op. cit.); ele a desenvolve em uma direção própria em DeLanda (A new philosophy of society: assemblage theory and social complexity. Londres: Continuum, 2006). Jensen (op. cit.) faz uma excelente análise das repercussões teóricopolíticas (equivocadas ou não) dessas ontologias, especialmente para o caso de Latour. Este último, em seu recente Reassembling the social, insiste sobre o imperativo metodológico de "manter o social plano", próprio da "teoria do ator-rede", cujo outro nome, aliás, seria "ontologia do actante-rizoma" (Latour, 2005: 9). A análise conceitual própria a esta teoria (seu método deobviação, diria Wagner) consiste no desenglobamento hierárquico do socius de modo a liberar as diferenças intensivas que o atravessam e destotalizam operação completamente diferente de uma rendição ao "individualismo", ao contrário do que clamam os retroprofetas do Velho Testamento holista.

[16] A "comparação controlada" éum método analítico famoso em etnolo- 
gia (F. Eggan. "Social anthropology and the method of controlled comparison". American Anthropologist, 56 pp. 743-63, 1954).

[17] R. Wagner. The invention of culture. $2^{\text {a }}$ ediçao revista e ampliada. Chicago: University of Chicago Press, 1981.

[18] J. Donzelot. An anti-sociology. Semiotext(e), II(3), p. 28, 1977.

[19] Idem, p. 37. "[No Anti-Édipo,] a derrubada da psicanálise [é] a condição preliminar para uma reviravolta de proporções completamente diferentes [...] temos aqui, ampliada à escala da totalidade das ciências humanas, uma tentativa de subversão do mesmo tipo geral daquilo que Laing e Cooper levaram a cabo no terreno estrito da psiquiatria" (Idem, p. 27)

[20]M. Strathern. The gender of the gift: problems with women and problems with society in Melanesia. Berkeley: University of California Press, 1988 E. Viveiros de Castro. "And. Manchester Papers". Social Anthropology, 7: 1-23, 2003.

[21] DG. "Préface pour l'édition italienne de Mille Plateaux". In: GD. Deux régimes de fous. Textes et entretiens 1975-1995 (D. Lapoujade, org.) Paris: Minuit, 2003 [1987], p. 290.

[22] "[Milles Plateaux] é um livro de conceitos" (GD. Pourparlers. Paris: Minuit, 1990 [1980], p.39.

[23] Sobre o modelo merológico, ver M. Strathern. After nature: English kinship in the late twentieth century. Cambridge: Cambridge University Press. 1992. Sobre a idéia do mundo pósplural, ver do mesmo autor Partial connections. Savage, Md.: Rowman and Littlefield 1991, p. xvi; After nature: English kinship in the late twentieth century,pp.3-4, 184 et passim; "Parts and wholes: refiguring relationships in a post-pluralworld".In:Reproducing the future: anthropology, kinship, and the new reproductive technologies. Nova York: Routledge, 1992, p. 92. Sobre o presentismo estratégico expresso na complexa construção "jamais fomos", ver, naturalmente, B. Latour. Nous n'avons jamais été modernes. Paris: La Découverte, 1991. A expressão "alternativa infernal" foi tomada de Pignarre e Stengers, op. cit.
Édipo é o resultado, com efeito, de um "prodigioso esforço para se pen-

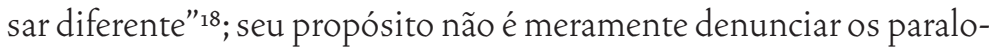
gismos repressivos do Édipo e da psicanálise, mas instaurar uma verdadeira "anti-sociologia". ${ }^{19} \mathrm{Um}$ projeto como esse deveria certamente interessar à antropologia contemporânea, pelo menos àquela que não se considera como um ramo menor, exótico e inofensivo, da sociologia, mas que ao contrário toma esta última como constituindo (via de regra...) uma modalidade particularmente confusa, e políticoepistemologicamente duvidosa, de "auto-antropologia"zo.

O segundo livro do díptico, Milplatôs(1981), distancia-se das preocupações psicanalíticas do Anti-Édipo. O projeto de escrever uma "história universal da contingência" 21 é aqui levado adiante de um modo decididamente não-linear, pela visitação de diversos "platôs" de intensidade (noção inspirada em Gregory Bateson) ocupados por formações semiótico-materiais as mais diversas, bem como por uma desconcertante quantidade de conceitos novos. ${ }^{22}$

O livro expõe e ilustra uma teoria das multiplicidades, talvez o tema deleuziano de maior repercussão na antropologia contemporânea.A multiplicidade deleuziana é o constructo que melhor parece descrever não só as práticas contemporâneas de conhecimento antropológico como os fenômenos de que elas se ocupam. Seu efeito é, antes de tudo, liberador. Ele consiste em fazer passar uma linha de fuga por entre os dois dualismos que formam como as paredes da prisão epistemológica em que a antropologia se acha encerrada (para a própria proteção, bem entendido) desde sua incepção: Natureza e Cultura, de um lado, Indivíduo e Sociedade, do outro, os "quadros mentais últimos" da disciplina, aqueles que não podemos pensar que estão errados porqueé através deles que pensamos. Não podemos? Pensamos? As coisas mudam, e com elas as possibilidades de pensamento; muda a idéia do que é pensar, e do que é pensável. O conceito de multiplicidade talvez só tenha se tornado, antropologicamente, pensável - e portanto, pensável antropologicamente - porque ingressamos em um mundo não-merológico e pós-plural, um mundo em que jamais fomos modernos: o mundo que deixou para trás, por desinteresse antes que por sublação, a alternativa infernal entre o Um eo Múltiplo, o grande dualismo que preside aos dois dualismos supramencionados, e a múltiplos outros. ${ }^{23}$

Multiplicidade é assim o meta-conceito que define um certo tipo de entidade, do qual o famoso "rizoma" da Introdução de Mil platôsé a imagem concreta ${ }^{24}$. Como observou Manuel DeLanda ${ }^{25}$, a idéia de multiplicidade é o fruto de uma decisão inaugural de natureza antiessencialista e anti-taxonomista: com sua criação, Deleuze pretende destronar as noções metafísicas clássicas de essência e de tipo ${ }^{26}$. Ela é o instrumento principal de um "prodigioso esforço" para pensar o 
pensamento como uma atividade outra que a de reconhecer, classificar e julgar, e para determinar o que há a pensar como diferença intensiva antes que como substância extensiva. As intenções ou implicações filosófico-políticas desta decisão são claras: transformar a multiplicidade em conceito e o conceito em multiplicidade visa cortar o vínculo natal entre o Conceito e o Estado. ${ }^{27}$

Uma multiplicidadeé diferente de uma essência; as dimensões que a compõem não são propriedades constitutivas ou critérios de inclusão classificatória. Um dos componentes principais do conceito de multiplicidade é, ao contrário, uma noção de individuação como diferenciação não-taxonômica - um processo de atualização do virtual diverso de uma realização do possível por limitação, e refratário às categorias tipológicas da semelhança, da oposição, da analogia e da identidade. A multiplicidade é o modo de existência da diferença intensiva pura, "a irredutível desigualdade que forma a condição do mundo" 28 . As noções de tipo e de entidade se mostram, em geral, completamente inadequadas para definir as multiplicidades rizomáticas. Se "não há entidade sem identidade", como Quine famosamente rimou, então deve-se concluir que as multiplicidades realmente não podem pretender tal estatuto. Um rizoma não se comporta como uma entidade, nem instancia um tipo; ele é um sistema reticular acentrado formado por relações intensivas ("devires") entre singularidades heterogêneas que correspondem a individuações extra-substantivas, ou eventos (as "hecceidades").Assim, uma multiplicidade rizomática não é realmente um ser, um "ente", mas um agenciamento de devires, um "entre": um difference engine (mas não exatamente a máquina de Babbage), ou, antes, o diagrama intensivo de seu funcionamento. Bruno Latour, que assinala a dívida da teoria do ator-rede para com o conceito de rizoma, é particularmente explícito: uma rede não é uma coisa, porque qualquer coisa pode ser descrita como uma rede 29 . Uma rede é uma perspectiva, um modo de inscrição e de descrição, "o movimento registrado de uma coisa à medida que ela vai se associando com muitos outros elementos"30. Mas essa perspectiva é interna ou imanente; as diferentes associações da "coisa" fazem-na ir diferindo de si mesma - "é a coisa ela própria que passou a ser percebida como múltipla" ${ }^{11}$. Em suma, não há pontos de vista sobre as coisas; as coisas e os seres é quesão os pontos de vista ${ }^{32}$. Se não há entidade sem identidade, não há multiplicidade sem perspectivismo.

Se ele não é um ser, um rizoma tampouco é um ser - nem, aliás, muitos. A multiplicidade não é algo maior que um, algo como uma pluralidade ou uma unidade superior; ela é, antes, algo menor que um, surgindo por subtração (importância da idéia de menor, minoria, minoração em Deleuze). Toda multiplicidade se furta à coordenação extrínseca imposta por uma dimensão suplementar $(n+1: n$ e seu "prin-
[24] Digo metaconceito porque todo conceito é ele próprio uma multiplicidade, embora nem toda multiplicidade seja conceitual (DG. Qu'est-ce que la philosophie?, pp. 21 ess).

[25] M. DeLanda, op.cit.

[26] O conceito deleuziano tem sua origem na filosofia de Bergson (teoria das duas multiplicidades, intensivas e extensivas), e na geometria de Gauss e Riemann (as variedades como superfícies $\mathrm{n}$-dimensionais intrinsecamente definidas). Para a conexão com Bergson, ver GD. Le bergsonisme. Paris: PUF, 1966, cap. 2; para Riemann, $M P$, pp. 602-9. Para os aspectos matemáticos gerais da multiplicidade deleuziana, ver, além da engenhosa reconstrução de DeLanda (Intensive science and virtual philosophy. Londres: Continuum, 2002, pp. 9-10, 38-40 et passim), os artigos de Duffy, Smith, Durie e Plotnitsky em Duffy (org.). Virtual mathematics: the logic of difference (Bolton: Clinamen Press, 2006). Le vocabulaire de Deleuze, de F. Zourabichvili (Paris: Ellipses, 2003, pp.51-4), traz o melhor resumo do significado filosófico do conceito na obra de Deleuze.

[27] Sobre a filosofia de Deleuze como um combate contra o sistema do julgamento, isto é, como respondendo à questão: o que é pensar, quando pensar não é julgar?, ver o importante estudo de Ovídio de Abreu, $O$ combate ao julgamento no empirismo transcendental de Deleuze. Tese de doutorado em filosofia, IFSCUFRJ, 2003.

[28] GD.Différence et répétition, p. 286.

[29] B. Latour. Reassembling the social. An introduction to Actor-Network theory. Oxford: Oxford University Press, 2005, pp.129-31.

[30] C. B. Jensen. "Latour and Pickering: post-human perspectives on science, becoming, and normativity". In: D. Ihde e E. Selinger (orgs.), Chasing technoscience: matrix for materiality. Bloomington: Indiana University Press, 2003, p. 227.

[31] B. Latour. Reassembling the social. An introduction to Actor-Network theory, p. 116.

[32] GD. Différence et répétition, p. 79; Logique du sens, p. 203. 
[33] R. Wagner. Symbols that stand for themselves. Chicago: The University of Chicago Press, 1986

[34] Registre-se, para ulterior consideração, a hipótese de que na obra de Wagner se ache a primeira e ainda única tentativa de criação de um conceito antropológico de conceito (E. Viveiros de Castro, op. cit.), ou, se se preferir não abusar do termo reservado por Deleuze à filosofia, a primeira determinação antropológica rigorosa da Figura (sensu DG. Qu'estce que la philosophie?), determinação que não a toma - ao contrário do que parece ser inevitável em filosofia como constituindo o exterior do conceito, isto é, como existindo lógica, se não cronologicamente "para" o conceito, "em vista" do conceito.

[35] $M P, \operatorname{pp} \cdot 13,27,31$

[36] (GD. Différence et répétition, p. 236). Uma multiplicidade ou rizoma é um sistema, note-se, não uma soma de "fragmentos". É simplesmente um outro conceito de sistema, que se distingue do sistema arborescente como um processo imanente se distingue de um modelo transcendente (MD, p.31)

[37] $M D$, p. 621

[38] Ou melhor, onde o todo é apenas uma parte ao lado das partes. "Só acreditamos em totalidades ao lado [à coté]. E se encontramos uma totalidade dessas ao lado de partes, é como um todo dessas partes, mas que não as totaliza, uma unidade de todas essas partes, mas que não as unifica, e que se acrescenta a elas como uma nova parte composta à parte. [...] O todo não coe xiste simplesmente com as partes, ele lhes é contíguo, é produzido ele próprio à parte, aplicando-se às partes [...]" (AE, pp. 50, 52; grifos originais). Sobre a heterogeneidade dos elementos conectados em rizoma, é importante ressalvar que ela não diz respeito a uma condição substantiva prévia, ou essência, dos termos (o que conta como heterogêneo, nesse sentido, depende das "predisposições culturais" do observador - M. Strathern. "Cutting the network". Journal of the Royal Anhtropological Institute, NS 2(4), 1996, p.525), mas a um efeito de sua captura por uma multiplicidade, a qual torna heterogêneos os termos que conecta, ao fazê-los funcionar como singularidades, "representantes de si mesmos". cípio", ne seu "contexto" etc.); a imanência da multiplicidade é autoposição, anterioridade ao próprio contexto. As multiplicidades são tautegóricas, como os símbolos wagnerianos que "representam a si mesmos"33, possuindo sua própria medida interna. 34 Uma multiplicidade é um sistema de $n-1$ dimensões 35 , em que o Um opera apenas como aquilo que deve ser retirado para produzir o múltiplo, que é então criado por "destranscendência"; ela manifesta uma organização "que pertence ao múltiplo como tal, e que não tem nenhuma necessidade da unidade para formar um sistema". ${ }^{36}$

As multiplicidades são assim sistemas cuja complexidade é "lateral", refratária à hierarquia ou a qualquer outra forma de unificação transcendente - uma complexidade de aliança antes que de descendência, para anteciparmos o argumento da segunda parte deste artigo. Formando-se quando e onde linhas intensivas abertas (linhas de força, não linhas de contorno ${ }^{37}$ ) conectam elementos heterogêneos, os rizomas projetam uma ontologia fractal que ignora a distinção entre "parte" e "todo" $3^{8}$. Uma concepção barroca antes que romântica de complexidade, como Kwa 39 persuasivamente argumentou. A multiplicidade é o quase-objeto que vem substituir aquelas totalidades orgânicas ("românticas") e aquelas associações atômicas ("iluministas") que pareciam esgotar as possibilidades à disposição dos antropólogos; com isso, ele sugere uma interpretação completamente diferente dos mega-conceitos emblemáticos da disciplina, a Cultura ou a Sociedade, a ponto de torná-los, em um sentido não trivial, "teoricamente obsoletos". ${ }^{40}$

A pessoa fractal de Wagner, as conexões parciais de Strathern, as redes sociotécnicas de Callon e Latour são alguns exemplos antropológicos bem conhecidos de multiplicidade plana. "Uma pessoa fractal nunca é uma unidade que está em relação com um agregado, ou um agregado em relação com uma unidade, mas sempre uma entidade com a relacionalidade [relationship] integralmente implicada". ${ }^{41} \mathrm{~A}$ imbricação dos conceitos de multiplicidade, implicação e intensidade é, como se sabe, um ponto longamente elaborado por Deleuze ${ }^{42}$. François Zourabichvili, o mais perceptivo comentador deste filósofo, observa que "a implicação é o movimento lógico fundamental da filosofia de Deleuze" 43 ; alhures, ele sublinha que o pluralismo deleuziano supõe um "primado da relação"44. A filosofia da diferença é uma filosofia da relação.

Mas não se trata de "qualquer" relação. A multiplicidade é um sistema formado por uma modalidade de síntese relacional diferente de uma conexão ou conjunção de termos. Trata-se da operação que Deleuze chama de sintese disjuntiva ou disjunção inclusiva, modo relacional que não tem a semelhança ou a identidade como causa (formal ou final), mas a divergência ou a distância; um outro nome deste modo 
relacional é "devir". A síntese disjuntiva ou deviré "o operador principal da filosofia de Deleuze"45, na medida em que é o movimento da diferença como tal - o movimento centrífugo pelo qual a diferença escapa ao poderoso atrator circular da contradição e sublação dialéticas. Diferença positiva antes que opositiva, indiscernibilidade de heterogêneos antes que conciliação de contrários, a síntese disjuntiva faz da disjunção "a natureza mesma da relação" 46 , e da relação um movimento de "implicação recíproca assimétrica" 47 entre os termos ou perspectivas ligados pela síntese, a qual não se resolve nem em equivalência nem em identidade superior:

A idéia mais profunda de Deleuze étalvez esta:que a diferença étambém comunicação e contágio entre heterogêneos; que, em outras palavras, uma divergência não surge jamais sem contaminação recíproca dos pontos de vista. [...] Conectar é sempre fazer comunicar os dois extremos de uma distância, mediante própria heterogeneidade dos termos. ${ }^{48}$

Voltando aos paralelos com a teoria antropológica contemporânea, recorde-se que o tema da separação relacionante é característico da antropologia de Marilyn Strathern. A concepção da relação como "compreendendo disjunção e conexão ao mesmo tempo [together]" 49 é a base de uma teoria que afirma que as "relações fazem uma diferença entre as pessoas" 50 . Pode-se dizer que o célebre "sistema M", a descrição stratherniana da socialidade melanésia como uma troca de perspectivas e um processo de implicação-explicação relacional, é uma teoria antropologicamente simétrica da síntese disjuntiva ${ }^{51}$. Do ponto de vista antropológico reflexivo, por sua vez, poderíamos dizer que a multiplicidade subtrativa $(n-1)$ antes que aditiva do rizoma faz dele uma figura analítica radicalmente não-merológica e "pós-plural" 52 , que dessa forma indica uma linha de fuga à alternativa entre o um e o múltiplo que Marilyn Strathern, com sua usual visada certeira, aponta como o impasse característico da antropologia:

Os antropólogos em geral têm sido encorajados a pensar que a alternativa ao umé o múltiplo. Em conseqüência disso, ora estamos às voltas com uns, a saber, com sociedades ou atributos singulares, ora com uma multiplicidade de uns [...] Um mundo obcecado por uns e pelas multiplicações e divisões de uns tem problemas com a conceitualização de relações. 53

Faz-se então necessária uma terapia de desobsessão. Comparar multiplicidades é outra coisa que fazer convergir particularidades em torno de generalidades, como no caso usual das análises antropológicas que buscam semelhanças substanciais por baixo de diferenças acidentais: "em toda sociedade humana...". Recorde-se uma
[39] "Romantic and baroque conceptions of complex wholes in the sciences". In: J. Law e A. Mol (orgs.). Complexities. Social studies of knowledge practices. Durham: Duke University Press, 2002.

[40] Strathern et al. "The concept of society is theoretically obsolete". In: T. Ingold (org.). Key debates in antrhopology.Londres: Routledge,1996 [1989]. Tenho que é preciso reavaliar a esquematização da história do pensamento ocidental recente, da antropologia em especial, em termos de uma combinação conflituosa (com dominância alternada) entre princípios românticos e iluministas. Essa estrutura de sabor quase mitológico (sensu LéviStrauss) pode ter tido um certo valor explicativo para, digamos, o primeiro século da disciplina, entre 1860 e 1970 (ou pelo menos esta é minha desculpa para ter lançado mãodela em umartigo de enciclopédia: cf. E. Viveiros de Castro. "O conceito de sociedade em antropologia". In: $A$ inconstância da alma selvagem e outros ensaios de antropologia.São Paulo: Cosac Naify, 2002). A partir dali, a aplicação do termo "(neo-)romântico" a diversas tendências do pensamento pós-estruturalista - geralmente com intenção difamatória - parece-me um simples automatismo reativo; a sensibilidade conceitual em questão, se ecoa alguma era prisca, é o barroco (ver, justamente, GD. Le pli. Leibniz et le baroque. Paris: Minuit, 1988), não o romantismo.

[41] R. Wagner. "The fractal person". In: M. Godelier e M. Strathern (orgs.).Bigmen and great men:personification of power in Melanesia. Cambridge: Cambridge University Press, 1991, p. 163. O "um homem e muitos homens" de M. Strathern (idem, ) não deixa de evocar uma multiplicidade deleuziana de tipo $n-1$, algo como um "muitos-menos-um homens". Se compreendo a autora corretamente, na estética melanésia a unidade de uma pluralidade provém de si mesma, não de um princípio exterior.Alternativamente, poder-seia imaginar ali uma multiplicidade de tipo $1-n$, já que, para recordarmos outro exemplo melanésio, "o maior número possível que os Iqwaye podem alcançar, e que alcançam, é um" (J. Mimica. Intimations of infinity: the cultural meanings of the Iqwaye couting and number system. Oxford: Berg, 1988, p. 95). 
[42] Différence et répétition, cap. VI.

[43] "Deleuze et la question de la littéralité”, p. 82, 2004 (MS inédito).

[44] Le vocabulaire de Deleuze. Paris: Ellipses, 2003, p. 52, n. 1. Pluralismo por oposição a dualismo (cf. $M P$, pp. 30-1).

[45] F. Zourabichvili. Le vocabulaire de Deleuze, p. 81 .

[46] Idem, "Deleuze et la question de la littéralité", p. 99.

[47] Idem, Le vocabulaire de Deleuze, p. 79 .

[48] Idem, "Deleuze et la question de la littéralité", p. 99.

[49] M. Strathern. "The nice thing about culture is that everyone has it". In: M. Strathern (org.). Shifting contexts: transformations in anthropological knowledge. Londres e Nova York: Routledge, 1995, p. 165

[50] Idem, Property, substance and effect: anthropological essays on persons and things. Londres: Athlone.1999, p. 126; "Cutting the network", ed.cit.,p. $525, e$, naturalmente, The gender of the gift: problems with women and problems with society in Melanesia. Berkeley: University of California Press, 1988 , cap. 8.

[51] A. Gell. "Strathernograms, or the semiotics of mixed metaphors". In: The art of anthropology: essays and diagrams. Londres: Athlone, 1999. A interpretação de Alfred Gell segundo a qual o "sistema M" exprime uma teoria das relações internas suscita uma questão que só será possível explorar em outro contexto: a da tradutibilidade recíproca entre a antropologia stratherniana e a doutrina deleuziana da exterioridade das relações, sobretudo na interpretação que ela recebe no livro recente de Manuel DeLanda (A new philosophy of society: assemblage theory and social complexity. Londres: Continuum, 2006). Penso que ambas as interpretações são (proveitosamente) discutíveis.

[52] M. Strathern. After nature: English kinship in the late twentieth century. Cambridge: Cambridge University Press, 1992. observação pontual de Albert Lautmann (o autor referencial de Deleuze para a matemática):

A constituição, por Gausse Riemann, de uma geometria diferencial que estuda as propriedades intrínsecas de uma variedade, independentemente de qualquer espaço em que esta variedade estaria mergulhada, elimina qualquer referência a um continente universal ou a um centro de coordenadas privilegiadas. 54

Se onde se lê geometria puser-se antropologia, as implicações são óbvias. (O que faria as vezes de uma variedade para a antropologia? Não é difícil imaginar.) Tudo aquilo que costuma ser ritualmente denunciado como uma contradição e um escândalo - descrever ou comparar variações sem pressupor um fundo invariável? mas onde estão os universais? que é da constituição biológica da espécie, das leis do simbólico, dos princípios da economia política? (para não falarmos da chamada realidade exterior) - torna-se subitamente concebível. Concebível em potência, não em ato, por suposto; mas ganha-se ao menos o direito de especular nessa direção. Não se diga que a antropologia estaria com isso praticando o contrabando de bens intelectuais alheios (a geometria diferencial); eles não são mais estrangeiros que aqueles que alimentam a ortodoxia antropológica sobre a comparação e a generalização, tributária que esta é de uma metafísica bimilenaraquela mesma metafísica, recorde-se, que não admitia em seus domínios quem não fosse geômetra. 55

Mas comparar multiplicidades também é outra coisa que estabelecer invariantes correlacionais por meio de analogias formais entre diferenças extensivas (oposições), como no caso das comparações estruturalistas, nas quais "não são as semelhanças, mas as diferenças que se assemelham" 56 . Comparar multiplicidades — sistemas de comparação em si mesmas e de si mesmas - édeterminar seus modos característicos de divergirem, suas distâncias internas e externas; aqui, a "análise comparativa" é uma "síntese separativa" (ou "disparativa" ${ }^{57}$ ). No que concerne às multiplicidades, não são as relações (extensivas) que variam, são as variações (intensivas) que relacionam: são as diferenças que diferem..$^{8} \mathrm{Como}$ escrevia há mais de um século o estranho sociólogo molecular Gabriel Tarde: "Averdade é que a diferença vai diferindo, e que a mudança vai mudando, e que, ao se darem assim como fim de si mesmas, a mudança $e$ a diferença atestam seu caráter necessário e absoluto". 59

As idéias do ultraleibniziano Gabriel Tarde, o grande adversário do ultrakantiano Durkheim, foram resgatadas da Terra das Teorias Perdidas por Deleuze ${ }^{6}$. Elas estão sendo desenvolvidas hoje por Bruno Latour e Maurizio Lazzarato, entre outros; Tarde conhece um renasci- 
mento. Chunglin Kwa, no artigo já citado, observava a "diferença fundamental entre a concepção romântica da sociedade como organismo e a concepção barroca do organismo como uma sociedade" ${ }^{61}$. Ora, esta é uma perfeita descrição da diferença entre as sociologias de Durkheim e de Tarde. Contra o caráter sui generis dos fatos sociais do primeiro, o "ponto de vista sociológico universal" do segundo afirma que "toda coisa é uma sociedade, todo fenômeno é um fato social"62. Posição que recusa qualquer validade à distinção entre indivíduo e sociedade, parte e todo, assim como ignora a pertinência de toda diferença entre o humano e o não-humano, o animado e o inanimado, a pessoa e a coisa. A ontologia fractal ("existir é diferir") e o sociologismo irrestrito de Tarde se acompanham de um "psicomorfismo universal": tudo são pessoas, "pequenas pessoas" ${ }^{63}$, pessoas dentro de pessoas - all the way down.

Diferença intensiva, diferença de perspectiva, diferença de diferenças. Nietzsche observava que o ponto de vista da saúde sobre a doença difere do ponto de vista da doença sobre a saúde. ${ }^{64}$ Talvez tenha sido essa observação que inspirou Roy Wagner a dizer, sobre suas relações iniciais com os Daribi: "o modo como eles não me compreendiam não era o mesmo modo como eu não os compreendia"65 — talvez a melhor definição antropológica de cultura já proposta. ${ }^{66}$ Pois a diferença nunca é a mesma, "o trajeto não é o mesmo nos dois sentidos": "Uma meditação sobre o perspectivismo nietzschiano dá a consistência positiva ao conceito [deleuziano] de disjunção: distância entre pontos de vista ao mesmo tempo indecomponível e desigual a si mesma, pois o trajeto não é o mesmo nos dois sentidos $[\ldots .].]^{\prime}{ }^{67}$

A comparação de multiplicidades - em outras palavras, a comparação enquanto produção de multiplicidade (ou "invenção da cultura") - é sempre uma síntese disjuntiva, justo como as relações que relaciona.

\section{DUALIDADES PARCIAIS}

Os textos deleuzianos parecem se comprazer na multiplicação de díades conceituais: diferença e repetição, intensivo e extensivo, nomádico e sedentário, virtual e atual, linha e segmento, fluxos e quanta, código e axiomática, desterritorialização e reterritorialização, menor e maior, molecular e molar, liso e estriado - a lista é longa, o vocabulário é luxuriante. Devido a tal assinatura estilística, Deleuze já foi classificado como filósofo dualista ${ }^{68}$, o que é, para dizê-lo educadamente, uma leitura apressada do modo de funcionamento de sua conceitualidade. ${ }^{69}$

É importante notar como a marcha expositiva dos dois livros de Capitalismo e esquizofrenia, nos quais pululam as dualidades, é a todo
[53] Idem, Partial connections. Savage, Md.: Rowman and Littlefield, 1991, pp. 52-3.

[54] Apud D. W. Smith. "Axiomatics and problematics as two modes of formalisation: Deleuze's epistemology of mathematics". In: S. Duffy (org.). Virtual mathematics: the logic of difference. Bolton: Clinamen Press 2006, p. 167, n. 39 .

[55] Neste novo espírito, ver a metacomparação antropológica entre tipos de multiplicidade sugerida por $\mathrm{M}$. Strathern: "[C]ontrastar tipos de multiplicidade é algo a considerar. Se falamos de origens múltiplas em relação às produções [works] euro-americanas, então a multiplicidade provém do modo pelo qual as pessoas são adicionadas umas aos empreendimentos das outras. Se falamos de origens múltiplas em relação à contrapartida melanésia disso, então a multiplicidade provém do modo pelo qual as pessoas se dividem uma das outras" (Kinship, law and the unexpectorg. Relatives are always a surprise. Cambridge University Press, 2005, p. 161). Note-se que não há evidências diretas de que a autora esteja aqui utilizando, nem sequer alusivamente, o conceito deleuziano. Ainda assim, talvez se pudesse ver na primeira multiplicidade de Strathern aquilo que Deleuze chamaria de uma multiplicidade "falsa", molar ou arborescente, ao passo que a segunda seria uma multiplicidade de tipo molecular e intensivo, "composta de partículas que não se dividem sem mudarde natureza" (MP,pp. 46, 603). Strathern prossegue, sobre o contraste que ela propõe entre as práticas de conhecimento melanésias e euro-americanas: "Não estou comparando coisas comparáveis [like with like]. Com efeito". Com efeito.

[56] C. Lévi-Strauss. Le totémisme aujourd'hui. Paris: Presses Universitaires de France, 1962, p. 111.

[57] F. Gordon ("O sexo dos caracóis: sugestões para uma antropologia reversa, disparativa e contra o Estado" In: http://abaete.wikia.com.), evocando G. Simondon.

[58] O que seria, aliás, uma glosa aceitável da fórmula canônica do mito (Lévi-Strauss. "La structure des mythes", 1958). A presença recorrente desta figura sinóptica nas Mythologiques e além atesta que o estrutura- 
lismo, ao contrário do que (se) pensa, não afirma realmente que todas as "diferenças que fazem a diferença" cabem dentro das proporcionalidades reversíveis do esquema totêmico.

[59] G. Tarde.Monadologie et sociologie.v. 1. In: E uvres de Gabriel Tarde.Le Plessis-Robinson: Institut Synthélabo, 1999 [1895], p.69. Ver também: G. Tarde. Monadologia e Sociologia. São Paulo: Cosacnaify, 2007.

[6o]Différence et répétition, pp. 104-5 n. 1,264 n. 1;MP,pp. 267-71; GD.Le pli. Leibniz et le baroque, p. 147

[61] C. Kwa, op. cit., p. 26.

[62] G. Tarde, op. cit., pp. 58, 67.

[63] Idem, p. 43.

[64] Ver GD. Logique du sens, pp. 2023. Do mesmo modo, na dialética do Mestre e o Escravo é o escravo que é dialético, não o mestre (GD.Nietzsche et la philosophie. Paris: PUF, 1962, p.11.

[65] R. Wagner, The invention of culture, 1981, p. 20.

[66]Veja-se a sutil dobradura que esta idéia recebe das mãos de M. Strathern: "o modo como cada um compreende o outro é comprometido pelo modo como cada um imagina que o outro compreende, mas que não pode saber [como é]" (M. Strathern. "On space and depth". In: J. Law e A. Mol (orgs.). Complexities: social studies of knowledge practices. Durham e Londres: Duke University Press, 2002, p. 109). Agradeço a Antonia Walford a sugestão da passagem.

[67] F.Zourabichvili. Le vocabulaire de Deleuze, p. 79; grifo no original).

[68] F. Jameson. "Marxism and dualism in Deleuze". The South Atlantic Quarterly, 96(3),pp.393-416,1997.

[69] Para uma interpretação mais interessante de Deleuze como filósofo da "dualidade imediata ou nãodialética", ver L. Lawlor. "The beginnings of thought: the fundamental experience in Derrida and Deleuze". In: P. Patton e J. Protevi (orgs.). Between Deleuze and Derrida. Londres: Continuum, 2003.

[70] Assim se passa com a dualidade entre a arborescência e o rizoma ("não momento interrompida por cláusulas adversativas, modalizações, especificações, involuções, subdivisões e outros deslocamentos argumentativos das distinções duais (ou outras) que tinham acabado de ser propostas pelos próprios autores. Tais interrupções metódicas são precisamente isso, uma questão de método, não de arrependimento após o pecado binário; elas são momentos perfeitamente determinados da construção conceitual. $7^{\circ}$ Nem princípios nem fins, as díades deleuzianas são sempre meios para se chegar alhures. O caso exemplar aquié, ainda, a distinção entre a raiz e o rizoma. Naquele queé talvez o trecho mais citado de Mil platôs, pode-se ler:

O que importa éque a árvore-raize o rizoma-canal não se opõem como dois modelos; a primeira age como modelo e como decalque transcendentes, ainda que engendre suas próprias fugas; o outro age como processo imanente que subverte o modelo e esboça um mapa, ainda que constitua suas próprias hierarquias, mesmo se suscita um canal despótico. Não se trata deste ou daquele lugar na terra, nem de um momento dado na história, menos ainda de tal ou qual categoria no espírito. Trata-se do modelo enquanto tal, que não cessa de se erguer e de desmoronar, e do processo enquanto tal, que não cessa de se prolongar, de se romper, e de recomeçar. Não se trata de um outro, de um novo dualismo. Problema da escrita [...]. Não invocamos um dualismo senão para recusar um outro. Servimo-nos de um dualismo de modelos apenas para atingir um processo que rejeita qualquer modelo. É preciso, a cada passo, corretores cerebrais que desfaçam os dualismos que não quisemos erguer mas pelos quais temos de passar. Chegar à fórmula mágica que buscamos todos: PLURALISMO = MONISMO, por via de todos os dua lismos que são o inimigo, mas o inimigo absolutamente necessário, o móvel que não paramos de mudar de lugar..$^{71}$

Além de descartar de passagem as leituras que reduzem sua filosofia a mais uma teoria do Grande Divisor, ${ }^{72}$ os autores ilustram aqui dois procedimentos característicos. Primeiramente, o tratamento dos conceitos de um modo "menor" ou pragmático, como instrumentos, pontes ou veículos antes que como objetos, significações ou destinações últimas; o filósofo como penseur sauvage. Daí o realismo com que Deleuze e Guattari lidam com as propensões dualistas do pensamento em modo inercial. No Anti-Édipo, afirmam uma concepção monista da produção desejante; no Mil platôs, desenvolvem uma teoria pós-pluralista das multiplicidades - duas empresas marcadamente não-dualistas. Nem por isso, entretanto, eles supõem que os dualismos sejam um obstáculo negociável apenas pela boa vontade. ${ }^{73} \mathrm{Os}$ dualismos são reais, não imaginários; não são o mero efeito de um viés "ideológico", mas o resultado de um funcionamento ou estado específico da máquina abstrata, a segmentação dura ou sobrecodificante. 
É necessário desfazer os dualismos porque, antes de tudo, eles foram feitos. Eé possível desfazê-los pela mesma razão, porque eles foram $f e i$ tos; pois os autores tampouco pensam que os dualismos sejam o horizonte de eventos da metafísica ocidental, o limite absoluto que só pode ser exposto (desconstruído) mas jamais atravessado pelos prisioneiros da Caverna. Para desfazê-los, porém, é importante evitar a armadilha circular que consistiria em negá-los ou contradizê-los; é preciso sair deles "calculadamente", ou seja, sempre pela tangente por uma linha de fuga.

Isto nos leva ao segundo procedimento.As dualidades deleuzianas são construídas e transformadas segundo um padrão recorrente, que as determina como multiplicidades mínimas - como dualidades parciais, diria um leitor de Strathern ${ }^{74}$. Assim, toda distinção conceitual começa pelo estabelecimento de um pólo atual-extensivo e de um pólo virtual-intensivo. A análise subseqüente consiste em mostrar como a dualidade muda de natureza conforme se a tome do ponto de vista de um pólo ou do outro. Do ponto de vista do pólo extensivo (arborescente, molar, rígido, estriado etc.), a relação que o distingue do segundo é tipicamente uma oposição: uma disjunção exclusiva e uma síntese limitativa, isto é, uma relação ela própria extensiva, molar e atual. Da perspectiva do outro pólo (intensivo, rizomático, molecular, dúctil, liso), porém, não há oposição, mas diferença intensiva, implicação ou inclusão disjuntiva do pólo extensivo pelo pólo intensivo ou virtual; a dualidade posta pelo primeiro pólo é revelada como a face, a fase ou o eco molar de uma multiplicidade molecular situada no outro pólo75. É como se cada pólo "apreendesse" sua relação com o outro segundo sua própria natureza; ou, dito de outro modo, como se a relação entre os pólos pertencesse necessária e alternativamente ao regime de um ou de outro pólo, o regime da contradição ou o regime da linha de fuga ${ }^{76}$; ela não pode ser traçada de fora, a partir de um terceiro pólo englobante. O perspectivismo - a dualidade como multiplicidade é aquilo que a dialética - a dualidade como unidade - precisa negar para se impor como lei universal.

Os dois pólos ou aspectos de uma dualidade qualquer são sempre ditos estar presentes e ativos em todo fenômeno ou processo. Sua relação é tipicamente conceitualizada como sendo de "pressuposição recíproca”, uma noção repetidamente avançada no Mil platôs77 no lugar da causalidade, linear ou dialética, da redução macro-micro, ou dos esquema hilemórficos e expressivos. De um ponto de vista antropológico, pode-se aproximar a pressuposição recíproca da dupla semiótica wagneriana da invenção e da convenção, em que cada modo de simbolização precipita ou "contra-inventa" o outro, segundo um esquema de alternância figura-fundo ${ }^{78}$. Ou ainda, do modo de funcionamento de certas dualidades analíticas centrais de The gender of the gift (1988), de estaríamos porém restaurando um simples dualismo...?" $M P$, p. 21), dois esquemas que não cessam de interferir um no outro. Assim com os dois tipos de multiplicidades, molares e moleculares, que se exercem sempre ao mesmo tempo e em um mesmo agenciamento - não há um dualismo de multiplicidades, mas apenas e sempre "multiplicidades de multiplicidades" (idem, p.47).Assim com a distinção entre forma da expressão e forma do conteúdo, que não funda nem um paralelismo nem uma representação entre ambas, mas "uma maneira pela qual as expressões se inserem nos conteúdos [...] onde os signos modificam [travaillent] as coisas elas próprias, assim como as coisas se prolongam e se desdobram por meio dos signos" (idem, p. 110). Assim com a oposição entre segmentar e centralizado, que deve ser substituída por uma distinção entre duas segmentaridades distintas mas inseparáveis, sempre imbricadas e justapostas (idem, pp. 255, 259). Assim, enfim, com os espaços liso e estriado, cuja diferença é dita ser complexa, tanto porque "os termos sucessivos das oposições consideradas não coincidem completamente" (liso/ estriado não é exatamente a mesma coisa que nômade/sedentário etc), como porque os dois espaços "não existem de fato senão por meio de suas misturas entresi" (idem,p.593).Emsuma, logo após distinguir dois pólos, processos ou tendências, a análise deleuziana, de um lado, desdobra a polaridade em outras, embutidas assimetricamente na primeira (produzindo assim uma "mistura" de jure), e, de outro lado, indica a mistura de facto dos pólos iniciais. "E tudo isso ocorre ao mesmo tempo" (idem, p. 273).

[71] MP,p.31.

[72] Antropólogos são, em geral, muito adeptos desse tipo de desconstrução sumária. Ver L. Rival “Trees, from symbols of life and regeneration to political artefacts". In: L. Rival (org.). The social life of trees. Anthropological perspectives on tree symbolism. Oxford: Berg, 1998, e A. Rumsey. "Trees, from symbols of life and regeneration to political artefacts". In: L. Rival(org.).The sociallife of trees. Anthropological perspectives on tree symbolism. Oxford: Berg, 2001, para dois exemplos em que se protesta contra uma suposta grande divisão, em Mil platôs, entre O Ocidente $=$ Arbores- 
cência e O Resto $=$ Rizoma. Os críticos mostram uma certa ingenuidade ao imaginar uma certa ingenuidade por parte dos criticados, que sabiam perfeitamente bem o que (não) estavam fazendo: "Estamos indo por um mau caminho, com todas essas distribuições geográficas. Um impasse; tanto melhor" (MP, p. 30).

[73] Ou pela má, como no caso daqueles pensadores que crêem bastar chamar alguém outro de dualista, ou de grande-divisor, para deixar eles mesmos de o serem.

[74] Partial connections.

[75] "Uma alternativa, uma disjunção exclusiva, é determinada em relação a um princípio que constitui, no entanto, os dois termos ou os dois subconjuntos, e que entra ele próprio na alternativa (caso totalmente diferente do que se passa quando a disjunção é inclusiva)" ( $A E$, p. 95, conforme a tradução brasileira de G. Lamazière). O padrão aparece cedo no corpus deleuziano. Veja-se o comentário à divisão de Bergson entre duração e espaço: ela não pode ser definida simplesmente como uma diferença de natureza, pois a diferença é antes entre a duração, que suporta e transporta todas as diferenças de natureza, e o espaço, que exibe apenas diferenças de grau. "Não há assim diferença de natureza entre as duas metades da divisão: a diferença de natureza está inteiramente do lado de uma delas" (GD. Le bergsonisme. Paris: PUF, 1966, p. 23).

[76] MP, pp. 263-4.

[77] Idem, pp. 59, 85, 111, 260, 629.

[78] (R. Wagner. The invention of culture, cap. 3) Wagner qualifica a relação de produção recíproca entre convenção e invenção cultural de "dialética" (idem, p. 52; o termo é amplamente utilizado pelo mesmo autor em Symbols that stand for themselves. Chicago: University of Chicago Press, 1986), o que pode confundir um leitor de Deleuze. Mas tal dialética, além de ser explicitamente caracterizada de não-hegeliana, traz logo à mente a pressuposição recíproca e a síntese disjuntiva: "uma tensão ou alternância semelhante a um diálogo entre duas concepções ou pontos de vista que simultaneamente se contradizem e se reforçam" (idem, The invention of culture, p. 52). Uma dialética sem resolução nem conciliação, em suma.
Strathern, como aquelas que presidem à economia lógica do gênero ou à articulação entre os modos de troca melanésios, em que um pólo-masculino ou feminino, mesmo - sexo ou sexo - oposto, troca mediata ou imediata - é sempre descrito como uma versão ou transformação do outro, "cada um fornece[ndo] o contexto e a base do outro", como resumiu Strathern em um contexto (justamente) muito diferente. ${ }^{79}$

Um ponto de grande importância é que a pressuposição recíproca determina os dois pólos de qualquer dualidade como igualmente necessários, visto que mutuamente condicionantes, mas não faz deles pólos simétricos ou equivalentes.Ainter-pressuposição é uma relação de implicação recíproca assimétrica: "o trajeto não é o mesmo nos dois sentidos". Assim, ao distinguir os mapas rizomáticos dos decalques arborescentes, Deleuze e Guattari observam que os mapas estão constantemente sendo totalizados, unificados e estabilizados pelos decalques, os quais por sua vez estão sujeitos a toda sorte de deformações anárquicas induzidas pelo processo rizomático. Mas, no final das contas, "o decalque deve sempre serprojetado de volta no mapa. Esta operação e a precedente não são de modo algum simétricas" 80 . E elas não são simétricas porque uma das operações trabalha em sentido contrário ao devir, que é o processo do desejo ${ }^{81}$, enquanto a outra trabalha a seu favor. O decalque é "perigoso", porque ele "injeta redundâncias" no mapa, organizando e neutralizando a multiplicidade rizomática:

Oque o decalque reproduz do mapa ou do rizoma são sempreseusimpasses, bloqueios, germes de enraizamento pivotante ou pontos de estruturação [...] Quando um rizoma é obstruído, arborificado, acabou, o desejo não flui mais; pois é sempre por rizoma que o desejo se move e produz. ${ }^{82}$

Essa relação assimétrica entre processos e modelos em pressuposição recíproca (na qual o rizoma é processo, precisamente, enquanto a árvore é modelo) recorda de perto a distinção entre a diferença e a negação desenvolvida em Diferença e repetição: a negação é real, mas sua realidade é puramente negativa; ela é apenas a diferença invertida, extensivizada, limitada e opositivizada ${ }^{83}$. Assim, apesar de Deleuze e Guattari advertirem mais de uma vez que não se trata de estabelecer um contraste axiológico entre o rizoma e a árvore, a segmentaridade flexível-molecular e a segmentaridade dura-molar e assim por diante ${ }^{84}$, resta que há sempre uma tendência e uma contra-tendência, dois movimentos inteiramente diferentes: a atualização e a contra-efetuação (ou cristalização) do virtual. O primeiro movimento consiste no decaimento das diferenças de potencial ou de intensidade, na medida em que estas se desdobram (se ex-plicam) na extensão e se encarnam em estados de coisas empíricos. O segundo é criador ou "implicador" da diferença, e, se é um movimento de retorno ou de 
causalidade reversa ${ }^{85}$, uma "involução criativa", nem por isso deixa de ser estritamente contemporâneo do primeiro, sendo sua condição transcendental, e enquanto tal inanulável. Este último movimento éo Evento ou Devir, pura reserva de intensidade - a parte, em tudo que acontece, que escapa à sua própria atualização ${ }^{86}$.

Mais uma vez, é inevitável aproximar essa assimetria de processos inter-implicados de certos aspectos da semiótica de Roy Wagner ${ }^{87}$. A natureza dita "dialética" ou obviacional da relação entre os dois modos wagnerianos de simbolização remete a um dos modos, a diferenciaçãoinvenção, ao passo que o contraste opositivo entre os dois modos é, enquanto tal, o resultado da operação do outro modo, a coletivizaçãoconvencionalização. E além disso, embora os dois modos estejam simultânea e reciprocamente ativos em todo ato de simbolização (eles operam um sobreo outro, pois não há nada além deles), há "toda a diferença do mundo" 88 entre as culturas cujo "contexto de controle" — nos termos de Mil platôs, a territorialização - é o modo convencional e aquelas em que o controleé o modo diferenciante. Se o contraste entre os modos não é, em si, axiológico, a cultura que favorece a simbolização convencional e coletivizante - a cultura que gerou a teoria da cultura enquanto "representação coletiva" — orienta-se na direção do decalque, bloqueando ou reprimindo a dialética da invenção, e por isso deve, em última análise, "ser projetada de volta no mapa". Do mesmo modo, o contraste avançado em The gender of the gift entre as socialidades do "dom" e da "mercadoria" é explicitamente assumido como interno ao mundo da mercadoria ${ }^{89}$, mas ao mesmo tempo tudo se passa como se a forma-mercadoria fosse uma transformação (ou deformação) da forma-dom antes que o contrário, na medida em que a análise de uma socialidade do dom nos obriga, como antropólogos, a apreendermos a particularidade dos pressupostos culturais da antropologia ela própria, e a decompor nossas próprias metáforas capitalísticas ${ }^{\circ}$. O ponto de vista do dom sobre a mercadoria não é o mesmo que o ponto de vista da mercadoria sobre o dom. Implicação recíproca assimétrica. ${ }^{91}$

II

\section{O ANTI-ÉDIPO E A CRÍTICA DO PARENTESCO}

Se há efetivamente uma assimetria implicativa que pode ser dita primária dentro do sistema conceitual deleuziano, ela reside na distinção entre o intensivo e o extensivo. A segunda parte deste artigo discute a relevância dessa distinção para a releitura feita em Capitalismo e esquizofrenia de duas categorias-chave da teoria clássica do parentesco, a aliança e a filiação. A escolha se justifica, em primeiro
[79] (Partial connections, p. 72). No modelo melanésio de parentesco e gênero, "cada relação só pode provir da outra [...] as relações conjugais e filiais são metáforas uma da outra, $e$ portanto uma fonte interna de reflexão" (M. Strathern. "Same-sex and cross-sex relations: some internal comparisons".In:T.Gregore D.Tuzin (orgs.). Gender in Amazonia and Melanesia. An exploration of the comparative method. Berkeley: University of California Press, 2001, p. 240). Nesse mesmo artigo, achamos a observação: "as relações de sexo oposto ao mesmo tempo alternam com as relações de mesmo sexo e contêm em si uma premissa intrínseca de alternância" (idem, p.227) - um claro exemplode pressuposição recíproca assimétrica. Em outra direção, observe-se que tratamento geral das dualidades analíticas (em que cada termo é uma versão do outro) por Marilyn Strathern, bem como sua concepção da troca melanésia como troca de perspectivas, poderiam ser comparados com proveito ao perspectivismo deleuziano.

[8o] (MD, p. 21; grifos originais.) $\mathrm{Na}$ abordagem do contraste liso/estriado, os autores insistem no mesmo ponto de método: embora em pressuposição recíproca, "os dois espaços [...] não se comunicam entre si da mesma maneira [...] os princípios da mistura [...] não são de forma alguma simétricos"; a passagem do liso ao estriado e vice-versa são "movimentos completamente diferentes" (idem, p. 593).

[81] Idem, p. 334 .

[82] Idem, pp. 21-2.

[83] GD. Différence et répétition, pp. 302 ess.

[84]MP,pp.31, 259-60.

[85] Idem, p. 537.

[86]DG. Qu'est-ce que la philosophie?, p. 147

[87] The invention of culture, pp. 51-3, 116,121-2.

[88] Idem, p. 51.

$[89]$ M. Strathern. The gender of the gift: problems with women and problems with society in Melanesia, pp. $16,136,343$. 
[9o]Idem, p.309.

[91] Essa mesma estratégia de evocar um dualismo apenas para deslocar outro também é empregada por Latour, por exemplo em seu livreto contra-crítico sobre os faitiches: "O duplo repertório dos modernos não reside em sua distinção entre fatos e fetiches, mas na [...] distinção, mais sutil, entre a separação de fatos e de fetiches que eles fazem na teoria, por um lado, e a passagem para uma prática que difere totalmente disso, por outro lado (B. Latour. Petite réflexion sur le culte moderne des dieux faitiches. Le PlessisRobinson: Les Empêcheurs de Penser en Rond, 1996, pp. 42-3). Ou, mais adiante: "A escolha proposta pelos modernos não é, portanto, entre realismo e construtivismo, mas entre essa própria escolha e a existência prática, a qual não compreende nem a formulação da escolha nem sua importância" (idem, p. 47). Isso poderia valer como ilustração do conceito deleuziano da síntese disjuntiva: a meta-relação entre as disjunções exclusiva ("a escolha") e inclusiva é, ela própria, uma disjunção exclusiva, do ponto de vista da primeira ("é preciso escolher!"), e inclusiva, do ponto de vista da segunda ("do que você está falando?").

[92]C. B. Jensen. "A nonhumanist disposition: on performativity, practical ontology, and intervention". Configurations, 12, pp. 229-61, 2004.

[93] L. Dumont. Introduction à deux théories d'anthropologie sociale. Groupes de filiation et alliance de mariage. Paris: Mouton, 1971

[94] A realidade (teórica) do antagonismo entre essas duas concepções de parentesco, a "teoria dos grupos de descendência" de origem britânica ea "teoria da aliança de casamento" de origem francesa, é algo discutível (D. Schneider. "Some muddles in the models: or, how the system really works". In: M. Banton (org.). The relevance of models for social anthropology. Londres: Tavistock 1965; A critique of the study of kinship. Ann Arbor: University of Michigan Press, 1984)

[95] M.Strathern. "Parts and wholes: refiguring relationships in a postplural world". In: Reproducing the future: anthropology, kinship, and the new reproductive technologies. Nova York: Routledge, 1992, p.101. lugar, porque o tratamento dado por Deleuze e Guattari a essas duas noções exprime com especial clareza um importante deslocamento teórico que ocorre entre Anti-Édipo e Mil platôs; em segundo lugar, porque ele sugere a possibilidade de uma transformação da antropologia do parentesco, de modo a alinhá-la com os desenvolvimentos "não-humanistas" (preferiria chamá-los de "pós-ocidentais") que hoje ocorrem em outros campos de investigação92. Pois a questão é, efetivamente, a da possibilidade de conversão das noções de aliançae de filiação, classicamente tomadas como as coordenadas básicas da sociogênese humana tal como efetuada em e pelo parentesco, em modalidades de abertura para o extra-humano. Em outras palavras, trata-se de saber como transformar essas noções, de operadores intra-antropológicos, em operadores trans-ontológicos. Se o humano não é mais uma essência, o que fazer do parentesco?

Após terem desempenhado um papel quase-totêmico na antropologia entre os anos 1950 e 1970, quando designavam duas concepções diametralmente opostas do parentesc093, as noções de aliança e de filiação, seguindo o destino geral do paradigma morganiano em que se inseriam, perderam subitamente seu valor sinóptico, assumindo a função mais modesta de meras convenções analíticas, isso quando não encerraram sua carreira ativa passando do uso à menção94. As páginas a seguir propõem uma interrupção reflexiva desse movimento, sugerindo que algumas partes da teoria clássica podem ser recicladas. Certamente não é o caso de se voltar ao statu quo ante e recomeçar os modelismos formais da aliança prescritiva, ou regredir à metafísica substancialista dos grupos de descendência. Trata-se, ao contrário, de imaginar os delineamentos possíveis de uma concepção rizomática do parentesco capaz de extrair todas as conseqüências da premissa segundo a qual "as pessoas são integradas por relações" (persons have relations integral to them 95 ). Se a teoria dos grupos de descendência tinha como seu arquétipo abstrato as idéias de substância e identidade (o grupo enquanto indivíduo metafísico), e a teoria da aliança matrimonial, as idéias de oposição e totalização (a sociedade como totalidade dialética), a perspectiva aqui sugerida busca na filosofia de Deleuze alguns elementos para uma teoria do parentesco enquanto diferença e multiplicidade (a relação como disjunção inclusiva).

A antropologia social ocupa um lugar destacado em Capitalismo \& esquizofrenia. Começando por Bachofen e Morgan, A origem da família e Totem e tabu, até chegar a Lévi-Strauss e Leach (estávamos em 1972), o primeiro livro do díptico reescreve do zero, por assim dizer, a teoria da socialidade primitiva. Seu principal interlocutor e alvo polêmico é o estruturalismo de Lévi-Strauss, a propósito do qual, e em larga medida contra o qual, são mobilizadas uma quantidade de referências 
teóricas e etnográficas, do funcionalismo de Malinowski ao estruturalfuncionalismo de Fortes, do experimento etnográfico de Griaule e Dieterlen ao etno-marxismo de Meillassoux e Terray, da segmentaridade relacional de Evans-Pritchard à dramaturgia social de Victor Turner. ${ }^{96}$

Para além de seus efeitos desintoxicantes gerais, o Anti-Édipo foi um livro que também marcou época - ou que deveria ter marcado - também do ponto de vista restrito da antropologia do parentesco. Ao recusar tomar a família como referente primário do desejo, definindo este como imediatamente social, o Anti-Édipo articulava, com efeito, uma justificativa filosófica geral (porque "extensível" aos assim chamados sistemas descritivos) para as posições antiextensionistas e anti-genealogistas então defendidas por diversos antropólogos. $\mathrm{O}$ argumento permanece importante ainda hoje ou voltou a sê-lo-, uma vez que a popularidade da interpretação genealógica ou "genética" do parentesco está em recrudescência, graças à difusão das cosmologias neoliberais dentro das ciências humanas, e ao fato de que a semântica extensionista continua embutida nas diversas teorias antropológicas que utilizam a noção de projeção metafórica para dar conta de modos de personificação vistos como "ilegais" em nossa cosmologia (como é o caso, por exemplo, do grande livro recente de Descola97).

A tese da identidade imediata entre produção desejantee produção social se enquadra na problemática mais ampla da literalidade na filosofia de Deleuze, ou melhor,em sua recusa de qualquer distinção entre discurso metafórico e não-metafórico ${ }^{98}$. Neste sentido, menos que sustentando uma interpretação "categorial" da semântica do parentesco, nos termos do debate clássico genealogia versus categoria, o que está em jogo no Anti-Édipo é, antes, um contraste entre interpretações intensivas-constitutivas e extensivas-regulativas das categorias e papéis de parentesco. Mais uma vez, uma aproximação com Wagner se impõe. Compare-se o que escreve este antropólogo sobre o caráter tautológico da noção de proibição do incesto - éimpossível separar relações, categorias e papéis de parentesco, visto que estes aspectos se interconstituem 99 - com os argumentos de Deleuze e Guattari sobre a impossibilidade do incesto:

[A] possibilidade de incesto exigiria tanto as pessoas como os nomes filho, irmã, mãe, irmão, pai. Ora, no ato incestuoso, podemos dispordas pessoas, mas elas perdem seus nomes na medida em que esses nomes são inseparáveis da proibição que os interdita enquanto parceiros sexuais. Ou então os nomes subsistem, mas não designam mais que estados intensivos pré-pessoais que poderiam perfeitamente "se estender" a outras pessoas [...].É que não se pode jamais usufruirao mesmo tempo da pessoa e do nome - o que seria contudo a condição do incesto. ${ }^{100}$
[96] A biblioteca etnológica de Deleuze e Guattari possui uma fornida seção "África", o que reflete as condições do meio antropológico francês de então, quando o africanismo era a subespecialidade de longe a mais difundida. Era entre os africanistas, além disso, que se achavam os principais focos de oposição ao estruturalismo lévi-straussiano.

[97] Par-delà nature et culture. Paris: Gallimard, 2006.

[98]F. Zourabichvili. "Deleuze et la question de la littéralité", 2004 (MS inédito).

[99] R. Wagner "Incest and identity: a critique and theory on the subject of exogamy and incest prohibition". Man, 7(4), pp. 601-13,1972. "Se a relação é parte da definição de uma categoria [...] então um enunciado de proibição de incesto relativo a categorias é a mais pura e trivial das tautologias [...]" (idem, p. 603).

[100] $A E$, p. 190. Ou ainda: "Na verdade, as pessoas globais - a própria forma das pessoas - não preexistem aos interditos que pesamsobre elase as constituem" (idem, p. 84).VerA.Adler e M.Cartry. "La transgression et sa dérision". L'Homme, 11(3), p. 7, 1971, para um provável fonte do argumento. 
[101] Lévi-Strauss. Les structures élémentaires de la parenté. La Haye: Mouton, 1967 .

[102] $A E$, pp. 224 ess.

[103] Ela já aparece no estudo sobre Nietzsche; cf. GD. Nietzsche et la philosophie, p. 155.

[104] MP,p.324.

[105] O contraste Mauss/Nietzsche feito no Anti-Édipo remete a um complexo pano de fundo polêmico. Ele envolve os nomes de Hegel, Kojève, Bataille, o Colégio de Sociologia, e, mais proximamente, os de LéviStrauss, Lacan e Baudrillard - entre outros. A "economia generalizada" derivada por Bataille de uma leitura nietzschiana do "Ensaio sobre o dom" não é praticamente mencionada no Anti-Édipo (mas ver op.cit., p. 225). O desprezo de Deleuze e Guattari pela categoria batailleana da transgressão (a observação é de Lyotard) talvez explique parcialmente este quasesilêncio. No ensaio sobre Klossowski incluído na Lógica do sentido, porém, Deleuze desenvolve um contraste entre troca, generalidade (equivalência) repetição falsa, de um lado, e dom, singularidade (diferença) e repetição autêntica, do outro lado. Tal contraste, se antecipa as teses do Anti-Édipo a respeito da troca (ele tambéméevocadona primeira página da Introdução de Diferença e repetição - ed. cit, p. 7), está de certa e ambígua forma conectado, via Klossowski, a Bataille: Deleuze escreve que Théodore, o herói de um dos romances de Klossowki, "sabe que a verdadeira repetição reside no dom, na economia do dom que se opõe à economia mercantil da troca (... homenagem a Georges Bataille)" (GD. Logique du sens, p.334; reticências no original).

[106] Ver $A E$, pp. 87-9, 129-34. No prefácio à edição italiana de Mil platôs, os autores comentam: “Anti-Édipo tinha uma ambição kantiana [... (DG. "Préface pourl'édition italienne deMille Plateaux", p. 289).

[107] Nossa espécie como o análogo biológico do ocidente antropológico, as outras espécies e os outros povos confundidos em uma comum alteridade privativa? Opção pelo colonialismo cosmológico. Perguntar-se sobre o que "nos" faz diferentes dos outros - animais, povos, tanto faz — já é uma resposta.
Mas voltemos ao estruturalismo. A concepção lévi-straussiana do parentesco, fundada na dedução transcendental da proibição do incesto enquanto condição da sociogênese $e^{101}$, é recusada por Deleuze e Guattari sob o argumento de que ela é uma generalização antropológica do Édipo. Os autores comparam desvantajosamente o "Ensaio sobre o dom" de Mauss (a referência maior de Lévi-Strauss) à Genealogia da moral de Nietzsche; o último, sugerem, deveria ser o verdadeiro livro de cabeceira dos antropólogos ${ }^{102}$. Mas essa diferença entre Mauss e Nietzsche talvez tenha sido um pouco exagerada. A distinção conceitual entre "troca" e "dívida" não é tão clara quanto os autores fazem-na parecer ${ }^{103}$. E a teoria nietzschiana da repressão proto-histórica de uma "memória biológica", necessária para a criação de uma "memória social", não é tão antipodal assim ao paradigma antropogenético compartilhado pelas teorias maussianas e estruturalistas da troca. Penso queé apenas quando Deleuzee Guattari determinam claramente o devir como anti-memória, no Mil platôs ${ }^{104}$, que se pode dizer que os termos do problema mudam radicalmente. ${ }^{105}$

Parece-me, sobretudo, que a crítica do parentesco feita no Anti-Édipo é parcial ou incompleta. O livro está firmemente amarrado a uma concepção "humanista" ou antropocêntrica da socialidade; seu problema filosófico continua a ser o problema da hominização. Os defeitos desse foco só se mostram, por suposto, desde o ponto de vista radicalmente anedipiano do Mil platôs, publicado uma década depois. O primeiro livro pretende ser uma crítica da psicanálise e do Édipo; o vocabulário é quase parodisticamente kantiano: ilusão transcendental, uso ilegítimo das sínteses do inconsciente, os quatro paralogismos do Édipo, e assim por diante ${ }^{106}$. Pretendendo-se uma Crítica da Razão Psicanalítica, o Anti-Édipo permanece com isso dentro do Édipo; é um livro necessariamente, pior, dialeticamente edipiano. Na verdade, não seria descabido imaginar os autores do Mil platôs afirmando, ao considerarem seu livro precedente, que toda e qualquer interrogação de tipo antropológicofilosófico sobre a distintividade da espécie ou condição humana, não importa o que sirva de signo ou causa de sua eleição (ou maldição) — a criação especial, a alma imortal, a cerebralização, a neotenia, a linguagem, o trabalho, o desejo, o tabu do incesto, a meta-intencionalidade, o inconsciente, a consciência - está irremediavelmente comprometida com o Édipo. Pois, com efeito, o objetivo de uma antropologia contemporânea não pode ser mais o de encontrar o sucedâneo da glândula pineal que faz os humanos "diferentes" do resto da "natureza". ${ }^{107}$ Tanto quanto possa interessar à natureza, essa diferença não faz muita diferença. Os antropólogos estarão mais bem ocupados estudando as diferenças que os humanos são efetivamente capazes de fazer; a diferença entre eles e os demais viventes é apenas uma entre muitas delas, e não necessariamente a mais nítida, a mais estável ou a mais importante. 
A limitação de foco do primeiro volume de Capitalismo e esquizofrenia talvez explique a interpretação sistemática da aliança como cumprindo a função de transmissora do triângulo edipiano, argumento que põe a parentalidade como anterior à conjugalidade (a primeira "se prolonga" na segunda) e a aliança como meramente instrumental para a filiação ${ }^{108}$. Em outras palavras, a crítica das "concepções troquistas" articulada pelo Anti-Édipo depende de uma contra-teoria do Édipo, dentro da qual a filiação e a produção, antes que a aliança e a troca, são primordiais. Neste e em outros sentidos, o Anti-Édipo é um livro antiestruturalista. Mas, se seus autores tomaram assim suas distâncias da avaliação lévi-straussiana da estrutura do parentesco humano, foi preciso primeiro que eles tivessem aceito alguns dos termos em que a questão do parentesco foi formulada antropologicamente por LéviStrauss. Eles parecem crer, por exemplo, que a aliança diz respeito ao parentesco, e que o parentesco diz respeito à sociedade. Eé isso justamente que vai mudar, do Anti-Édipo ao Mil platôs.

\section{DA FILIAÇÃO INTENSIVA}

Contra o tema da troca como síntese sociogenética de interesses contraditórios, o Anti-Édipo avança o postulado de que a máquina social responde ao problema da codificação dos fluxos "fugitivos" de desejo. Deleuze e Guattari propõem uma concepção que é ao mesmo tempo inscritora - a tarefa do socius é marcar os corpos, a circulação é uma atividade secundária ${ }^{109}$ — e integralmente producionista: "tudoé produção" 110 . No melhor estilo Grundrisse, a produção, a distribuição e o consumo são postos como diferentes momentos de uma Produção vista como processo universal. A inscrição é um momento desse processo, o momento do registro ou codificação da produção, que contraefetua um socius fetichizado como instância do Dado natural ou divino, superfície mágica de inscrição e elemento de anti-produção (o chamado Corpo sem Órgãos).

O capítulo 3, parte central e mais longa do livro, começa por uma exposição das características da "máquina territorial primitiva" e de sua característica "declinação" da aliança e da filiação" ${ }^{11}$. A hipótese fundamental na construção de uma teoria alternativa ao estruturalismo, a esse respeito, consiste em fazer a filiação aparecer duas vezes, a primeira vez como estado genérico e intensivo do parentesco, a segunda como estado particular e extensivo em oposição complementar à aliança. A aliança aparece apenas no momento extensivo; sua função é precisamente a de extensivizar e codificar o parentesco, isto é, atualizá-lo.

Deleuze e Guattari postulam a existência primordial de uma filiação pré-cosmológica intensa, germinal, disjuntiva, noturna e ambí-

[109] Idem, pp. 217e ss.

[110] Idem, p.10, eu grifo.

[111] Idem, p.171. 
[112] Idem, p.191.

[113] Idem,p.181. Note-sequecrítica deleuziana ao extensionismo genealógico não implica um sociologismo anti-biológico: "É inútil dizer que a filiação é social e não biológica - ela é necessariamente bio-social, na medida em que se inscreve no ovo cósmico do corpo pleno da terra" (idem, p. 181). Mas é igualmente desnecessário lembrar que esse ovo biocósmico é um personagem completamente diferente, por exemplo, do gene egoísta.

[114] M. Griaule e G. Dieterlen. Le renard pâle. Paris: Institut d'Ethnologie, 1965 .

[115] O artigo de A. Adler e M. Cartry (op. cit.) sobre o mito Dogon está na origem da importância conferida aos materiais Dogon; ele é citado em momentos cruciais da análise. Esses dois antropólogos, junto com A. Zempléni, leram atentamente o rascunho do terceiro capítulo do Anti-Édipo (cf. S. Nadaud. "Les amours d'une guêpe et d'une orchidée". In: F. Guattari.Écrits pourl'AntiEdipe (textos organizados por $\mathrm{S}$ Nadaud). Paris: Éditions Lignes et Manifestes, 2004,pp. 20-1).Ao mesmo tempo, as idéias de Deleuze e Guattari tiveram uma influência determinante sobre o estudo de Adler e Cartry (op. cit., p. 37 n.1).

[116] $A E$, pp. 67, 99,134.

[117] Idem,pp.181-95

[118] $A E$, p. 185

[119] No sentido de $M P$,pp. 147 ess.

[120] M. Detienne. Les maîtres de vérité en Grèce archaïque. Paris: François Maspero, 1981 [1967]. gua, um "implexo" ou "influxo germinal" 112 queéo primeiro caráter de inscrição marcado sobre o corpo pleno e inengendrado da terra: "força pura da filiação ou genealogia. Numen"113. Essa análise do parentesco primitivo se apóia fundamentalmente em uma interpretação das narrativas míticas coletadas por Marcel Griaule e sua equipe, em particular no célebre mito de origem dos Dogon publicado em Le renard pâle ${ }^{114}$ : o ovo cósmico Amma, a Terra placentária, o trickster incestuoso Yuruggu, os Nommo, "gêmeos" hermafroditas e semi-ofidiomorfos, e assim por diante.

O papel que a narrativa desempenha no capítulo 3 ("Selvagens, bárbaros, civilizados") é de grande relevância teórica. Ela funciona como uma espécie de anti-mito de Édipo, ou talvez como o "mito do Anti-Édipo". ${ }^{115}$ No capítulo 2 ("Psicanálise e familialismo"), os autores haviam desenvolvido longamente um contraste entre as concepções teatral-expressiva e maquínico-produtiva do inconsciente, contraste que os levara a colocar mais de uma vez a questão impaciente: "por que voltar ao mito?" ${ }^{116}$, criticando o uso feito pela psicanálise da velha narrativa grega. Quando os autores levam a cabo sua reconstrução da antropologia do parentesco no capítulo seguinte ${ }^{117}$, porém, constata-se que são eles mesmos que, no fim das contas, "voltam ao mito". A introdução dos materiais Dogon, com efeito, não se faz sem uma radical reapreciação do conceito de mito por Deleuze e Guattari. Citemos a passagem pertinente:

[O] recurso ao mitoé indispensável, não porque ele seja uma representação transposta ou mesmo invertida das relações reaisemextensão, mas porque apenas o mito determina conformemente ao pensamento e à prática indígenas as condições intensivas do sistema (o sistema de produção inclusive). ${ }^{118}$

Essa avaliação aparentemente discordante, dentro do Anti-Édipo, do recurso ao mito exigiria uma consideração mais profunda do que me sinto em condições de fazer no momento. A título de especulação, diria que o que vemos, entre as referências à história de Édipo e ao ciclo da Raposa Pálida, é menos uma diferença de atitude em relação a um mesmo mito que uma diferença no mito mesmo, uma diferença interna ao que chamamos "mito": a história de Édipo pertence ao regime (bárbaro) do significante despótico, ao passo que a narrativa Dogon pertenceria melhor ao regime selvagem da semiótica primitiva ou "pré-significante"119. Não se trata pois de um mesmo mito, de um mesmo outro genérico do logos; há mito e mito. A questão do sentido inteiramente diverso que assume a enunciação mítica quando saímos do mundo pré-filosófico dos "Mestres da Verdade"120 e seu regime monárquico de enunciação, mundo "clássico" do helenista, do historiador da filosofia, para entrar no mundo extra-filosófico das "socieda- 
des contra o Estado", mundo do pensamento selvagem, da alteridade antropológica radical - bem, essa questão ainda não recebeu um desenvolvimento à altura. ${ }^{121}$

Mas o meta-mito Dogon não é um exemplo qualquer de mitopoiese selvagem. Ele é um mito cosmogônico de uma população da África Ocidental, região onde viceja uma cultura do parentesco marcada pelas idéias de ancestralidade e descendência, e pela presença de agrupamentos políticos constituídos na base de uma origem parental comum (linhagens). Não é de surpreender, assim, que os autores do Anti-Édipo cheguem com o auxílio desse mito à filiação como dimensão originária da relacionalidade de parentesco, evejam a aliança como uma dimensão apenas superveniente, cuja função seria a de diferenciar as afiliações linhageiras. Estamos no interior de um universo de parentesco classicamente fortesiano ${ }^{122}$. O que é intenso e primordial são as linhagens filiativas ambíguas, involuídas, implicadas e (pré) incestuosas, as quais perdem seu uso inclusivo e ilimitativo na medida em que, sendo o objeto de uma memória "noturna e biocósmica", devem "sofrer o recalque" exercido através da aliança para que se possam explicar e atualizar no espaço físico do socius. ${ }^{123}$

Mas tudo se passa como se o sistema dos Dogon, que são sinedoquicamente os Selvagens naquela altura do Anti-Édipo, exprimissem a teoria da descendência no plano virtual ou intensivo e a teoria da aliança no plano atual ou extensivo. Pois os autores fazem inteiramente suas as críticas de Leach a Fortes a respeito da "filiação complementar", assim como concluem, de uma demonstração de LéviStrauss sobre a lógica do casamento de primos cruzados ${ }^{124}$, que "em momento algum [...] a aliança deriva da filiação", e que "nesse sistema em extensão, não há filiação primeira nem geração primeira ou troca inicial, mas já e desde sempre alianças [...]". ${ }^{125} \mathrm{Na}$ ordem do extensivo, a filiação se reveste de um caráter "administrativo e hierárquico", ao passo que a aliança, que nesta ordemé primeira,é "política e econômica"126. O afim, o aliado de casamento como personagem sociopolítico, está lá desde o princípio para impedir o fechamento edipiano da família diante do socius, ao fazer com que as relações familiares sejam sempre relações coextensivas ao campo social ${ }^{127}$. Mas existe algo antes do princípio: na ordem da gênese metafísica, isto é, do ponto de vista mítico ${ }^{128}$, a aliança é segunda. O sistema em extensão nasce das condições intensivas que o tornam possível, mas ele reage sobre elas, elas as anula e recalca, não lhes permitindo senão uma expressão mítica ${ }^{129}$. (Fica a questão de saber o que seria uma expressão mítica em sentido não trivial, já que o mito "não é expressivo, mas condicionante"130.)

O campo do parentesco pós-proibição do incesto é, portanto, concebido em termos de uma relação de pressuposição recíproca
[121] VerM. Richir ("Qu'est-cequ'un dieu? Mythologie et question de la pensée". In: F.-W. Schelling. Philosophie de la mythologie. Paris: Jerome Millon, 1994), para algumas sugestões interessantes. $O$ conhecido debate entre Lévi-Strauss e Ricœur a respeito da análise estrutural dos mitos se radica nessa diferença.

[122] M. Fortes. Kinship and the social order: the legacy of Lewis Henry Morgan. Londres: Routledge \& Kegan Paul,1969, e Rules and the emergence of society. Londres: Royal Anthropological Institute of Great Britain and Ireland, 1983 .

[123] $A E$, p. 183 .

[124] Lévi-Strauss. Les structures élémentaires de la parenté, pp.151-4.

[125] $A E$, p. 184. Ver também: "nas estruturas de parentesco, é difícil evitar proceder como se as alianças derivassem das linhas de filiação e das relações entre elas, embora sejam as alianças laterais e os blocos de dívida que condicionam as filiações estendidas do sistema em extensão, e não o contrário" (idem, p. 220). Este é um raciocínio estruturalista típico.

[126] Idem, p. 172.

[127] Idem, p.196.

[128] Idem, p. 185 .

[129] Idem, p. 188 .

[130] Idem, p.185. 
[131] Lévi-Strauss. Les structures élémentaires de la parenté, pp. 569-70, grifo no original.

[132] C.Lévi-Strauss e D.Eribon.De près et de loin. Paris: Odile Jacob, 1988 p. 193.

[133] $M P$, p. 182 . entre a aliança e a filiação, comandada atualmente (político-economicamente) pela primeira e virtualmente (miticamente) pela segunda. O plano intensivo do mito é povoado por filiações (pré)incestuosas que ignoram a aliança. A noção de uma afinidade intensiva seria nesse caso auto-contraditória, ou quase isso. O mito éintensivo porque (pré-)incestuoso, e vice-versa: a aliança é de fato o princípio da sociedade, e o fim do mito. É difícil não se recordar aqui do último parágrafo das Estruturas elementares do parentesco, onde Lévi-Strauss observa que, em seus mitos sobre a Idade de Outro e o Além, "a humanidade sonha em capturar e fixar aquele instante fugidio em que lhe foi permitido crer que podia trapacear com a lei da troca, ganhando sem perder, desfrutando sem partilhar", e que assim para ela a felicidade completa, "eternamente negada ao homem social", é aquela que consisteem "viver entre si" ${ }^{131}$. Mas compare-se essa constatação, finalmente tão freudiana, com um outro passo célebre da obra de LéviStrauss, na qual o antropólogo define o mito como sendo "uma história do tempo em que os humanos e os animais não se distinguiam uns dos outros" ${ }^{132}$, acrescentando que a humanidade jamais conseguiu se resignar diante da falta de acesso comunicativo às outras espécies do planeta. Ora, a nostalgia de uma comunicação originária entre todas as espécies não é exatamente a mesma coisa que aquela nostalgia da vida "entre si" responsável pela fantasia do incesto póstumo. Muito ao contrário. Ou não?

Reformulando o problema nos termos da economia conceitual deleuziana, parece-me que o aspecto crucial da análise do mito Dogon é a determinação da filiação intensiva como operador da síntese disjuntiva de inscrição - o(s) Nommo que é/são um e dois, homem e mulher, humano e ofídio; a Raposa Pálida queéao mesmo tempo filho, irmão e esposo da Terra etc. —, ao passo que a aliança é o operador da síntese conjuntiva:

Assiméa aliança, a segunda característica da inscrição: a aliança impõe às conexões produtivas a forma extensiva de uma conjugação de pessoas, compatível comas disjunções da inscrição, mas, inversamente, ela reage sobre a inscrição ao determinar um uso exclusivo e limitativo dessas próprias disjunções. É assim inevitável que a aliança seja representada miticamente como sobrevindo, a partir de um certo momento, às linhas filiativas (ainda que, em outro sentido, ela sempre tenha estado lá).133

Vimos mais acima que a síntese disjuntiva é o regime relacional característico das multiplicidades. Como se lê logo em seguida ao trecho acima, o problema não é o de ir das filiações às alianças, mas "o de passar de uma ordem energética intensiva a um sistema extensivo". E nesse sentido, "o fato de que a energia primária da ordem 
intensiva [...] seja uma energia de filiação não muda nada, pois esta filiação intensa ainda não está estendida, não comportando ainda nenhuma distinção entre pessoas, ou mesmo entre os sexos, mas apenas variações pré-pessoais em intensidade [...]"134. Aqui caberia apenas acrescentar que se essa ordem intensiva não conhece distinção de pessoas nem de gêneros, tampouco conhece qualquer distinção de espécies, particularmente uma distinção entre humanos e não-humanos: no mito, todos os actantes ocupam um campo interacional único, ao mesmo tempo ontologicamente heterogêneo e sociologicamente contínuo; ali onde toda coisa é "humana", o humano é toda uma outra coisa. ${ }^{135}$

Abre-se então a questão: se o fato da energia primária ser uma energia de filiação não muda nada,é possível determinar uma ordem intensiva onde a energia primária seja uma energia de aliança? É realmente necessário que a aliança funcione apenas e sempre para ordenar, discernir, discretizar e policiar uma filiação pré-incestuosa anterior? Ou seria concebível uma aliança intensa, anedipiana, que compreenda "variações pré-pessoais em intensidade"? Em poucas palavras, o problema é o de imaginar um conceito de aliança como síntese disjuntiva.

Para fazê-lo, teríamos de tomar uma distância um pouco maior da cosmologia lévi-straussiana do que faz o Anti-Édipo, ao mesmo tempo em que precisaríamos submeter o conceito de troca a uma interpretação deleuziana ou "perversiva"136. Minimamente, isso significa abandonar a descrição do "átomo de parentesco" em termos de uma alternativa exclusiva - esta mulher como sendo ou minha irmã ou minha esposa, este homem como sendo ou meu irmão ou meu cunhado - e reformulá-la em termos de uma disjunção inclusiva ou não-restritiva: "seja...seja...", "e/ou". A diferença entre irmã e esposa, irmão e cunhado deve ser tomada como uma diferença interna, "indecomponível e desigual a si mesma". O que dizem os autores sobre o esquizofrênico e as disjunções masculino/feminino, morto/vivo que ele confronta, valeria também nesse caso: uma determinada mulheré de fato minha irmã ou minha cunhada, mas ela "pertence precisamente a ambos os lados", irmã do lado das irmãs (e irmãos), esposa do lado das esposas (e maridos) - não ambas as coisas ao mesmo tempo para mim, "mas cada uma das duas enquanto pontos terminais de uma distância que el[a] sobrevoa deslizando". ${ }^{137}$

O ponto pode ser reformulado em uma linguagem que todo antropólogo reconhecerá138. Minha irmã é minha irmã na medida exata e exclusiva em que ela é uma esposa de (ou para) outrem, e viceversa.É a relação de sexo oposto entre mim e minha irmã/esposa que gera minha relação de mesmo sexo com meu cunhado. Assim, as relações de sexo oposto não apenas geram as relações de mesmo sexo, como lhes comunicam seu próprio potencial diferencial interno.
[134] Idem, p.183.

[135] E. Viveiros de Castro. "Perspectival anthropology and the method of controlled equivocation". Tipití, 2(1), p. 16, 2004.

[136] A teoria lévi-straussiana da troca matrimonial continua sendo, no final das contas, uma construção antropológica muito mais interessante que a doutrina juralista dos grupos de filiação. Em certo sentido, $A s$ estruturas elementares do parentesco foram o primeiro Anti-Édipo, ao marcarem uma ruptura radical com a imagem do parentesco centrada na família e dominada pela parentalidade; ou, para dizê-lo diferentemente, a relação do Anti-Édipo com As estruturas elementares é análoga à relação deste último livro com Totem e tabu.

[137] $A E$, p.9o.

[138] M. Strathern. The gender of the gift: problems with women and problems with society in Melanesia, 1988, e "Same-sex and cross-sex relations: some internal comparisons", 2001. 
[139] Veja-se a análise que faz $\mathrm{R}$. Wagner ("Analogic kinship: a Daribi example". American Ethnologist, 4(4), pp. 623-42, 1977) da troca matrimonial para os Daribi melanésios: o clã patrilinear doador de esposas vê as mulheres que cede como um fluxo eferente de sua própria substância masculina; mas o clã receptor verá o fluxo aferente como constituído de substância feminina; quando as prestações matrimoniais fazem o caminho inverso, a perspectiva se inverte. $O$ autor conclui: "Aquilo que se poderia descrever como troca, ou reciprocidade, é, na verdade, uma [...] imbricação de duas visões de uma só coisa" (idem, p. 628). E ver A. Gell, "Strathernograms, or the semiotics of mixed metaphors" (In:The art of anthropology: essays and diagrams. Londres: Athlone, pp. 67-8, 1999), para a exposição detalhada dessa idéia no vocabulário analítico de M. Strathern, autora que a levou imensamente adiante da formulação original, ao estabelecer toda troca, nas "economias do dom", como uma troca de perspectivas.

[140] $A E$, p. 82 .

[141] $A E$, p. 186.
Dois cunhados estão relacionados da mesma maneira que as díades de sexo cruzado que fundam sua relação (irmão/irmã, marido/mulher): não a despeito de sua diferença, mas por causa dela. Um dos cunhados vêa face conjugal de sua irmã no marido desta; o outro, o lado sororal de sua esposa no irmão desta. Um vê o outro como determinado pelo laço de sexo oposto que os diferencia a ambos: cada um vê-se a si mesmo como "de mesmo sexo" na medida em que o outro é visto "como" de sexo oposto, e reciprocamente. As duas faces do termo relacionante criam, dessa forma, uma divisão interna aos termos relacionados. Todos se tornam duplos, o relator e os relacionados revelam-se permutáveis sem por isso se tornarem redundantes; cada vértice do triângulo da afinidade inclui os outros dois vértices como versões de si mesmo' ${ }^{139}$. Essa duplicação complexa (na qual há, note-se de passagem, dois triângulos, um para cada sexo tomado como "relator") é explicitamente descrita por Deleuze e Guattari em um comentário sobre a analogia entre homossexualidade e reprodução vegetal feita em Sodoma e Gomorra. Algo como um "átomo de gênero" pode ser entrevisto aqui:

O tema vegetal [...] nos traz uma outra mensagem e um outro código: cada um de nós é bissexuado, cada um possui os dois sexos, mas separados, não-comunicantes; o homem é apenas aquele em quem a parte masculina predomina estatisticamente, a mulher, aquela em quem a parte feminina domina estatisticamente. De tal forma que, no plano das combinações elementares, é preciso fazer intervir pelo menos dois homens e duas mulheres para constituir a multiplicidade na qual se estabeleçam comunicações transversais [...] a parte masculina de um homem pode se comunicar com a parte feminina de uma mulher, mas também com a parte masculina dessa mulher, ou com a parte feminina de outro homem, ou ainda com a parte masculina desse homem etc. ${ }^{140}$

"Pelo menos dois homens e duas mulheres". Se os ligássemos como se por uma "troca de irmãs", isto é, por um arranjo matrimonial entre dois pares de germanos de sexo oposto (dois "divíduos" bissexuais, em suma), teríamos uma versão extensiva, classicamente estruturalista, da multiplicidade gênero. Mas, evidentemente, "tudo deve ser interpretado em intensidade" 141 . Este é o trabalho que o pequeno "etc." ao fim da passagem acima parece estar fazendo.

\section{À ALIANÇA demoníaca}

A possibilidade de uma interpretação intensiva da aliança só se torna concebível a partir de Mil platôs. Muitas coisas mudam, do AntiÉdipo ao segundo livro. Mas a mudança realmente importante, do 
ponto de vista limitado deste artigo, é introduzida no décimo platô, “1730: Devir-intenso, devir-animal, devir-imperceptível...". É ali que se acha a exposição do conceito de devir, exposição que arrasta toda a conceitualidade deleuziana em um singular devir-outro. A noção de devir é central em Deleuze desde seus estudos sobre Bergson e Nietzsche, e ocupa o lugar que se sabe na Lógica do sentido. Mas a partir do ensaio a quatro mãos sobre Kafka ${ }^{142}$ ela adquire uma inflexão e uma intensidade conceitual singulares, que atingirão sua "velocidade de escape" no capítulo 10 de Mil platôs. O devir é literalmente o que escapa tanto à mimesis - a imitação e a reprodução - quanto à "memesis" - a memória e a história. O devir é amnésico, pré-histórico, anicônico e estéril; ele é a diferença na prática.

O capítulo começa com uma exposição do contraste estabelecido por Lévi-Strauss ${ }^{143}$ entre as lógicas serial-sacrificial e totêmicoestrutural: a identificação imaginária entre o humano e o animal, de um lado, a correlação simbólica entre diferenças sociais e diferenças naturais, do outro. Entre esses dois modelos analógicos, a série e a estrutura, os autores de Mil platôs introduzem o motivo bergsoniano do devir, um tipo de relação irredutível tanto às semelhanças seriais como às correspondências estruturais. $O$ conceito de devir designa uma relação cuja apreensão é dificultosa dentro do quadro analítico do estruturalismo, no qual as relações funcionam como objetos lógicos molares, apreendidos essencialmente em extensão (oposições, contradições, mediações). Devir é uma relação real, molecular e intensiva que opera em um registro outro que o da relacionalidade ainda apenas epistêmica do estruturalismo ${ }^{144}$. A síntese disjuntiva do devir não é possível segundo as regras dos jogos combinatórios das estruturas formais; ela opera nas regiões longe do equilíbrio habitadas pelas multiplicidades reais ${ }^{145}$. "O devir e a multiplicidade são uma coisa só" 146 .

Se as semelhanças seriais são imaginárias e as correlações estruturais, simbólicas (neste sentido, são ambas edipianas, ou "míticas", no sentido negativo que a palavra tem no capítulo 2 do Anti-Édipo), os devires são reais. Nem metáfora, nem metamorfose, um devir é um movimento que desterritorializa ambos os termos da relação que ele estabelece, extraindo-os das relações que os definiam anteriormente para associá-los através de uma nova "conexão parcial". O verbo devir, neste sentido, não designa uma operação predicativa ou uma ação transitiva: estar implicado em um devir-onça não é a mesma coisa que virar uma onça. É o devir ele próprio que é felino, não seu "objeto". Pois tão logo o homem se torna um jaguar, o jaguar não está mais lá. "Lévi-Strauss não cessa de encontrar, em seus estudos sobre os mitos, esses atos rápidos pelos quais o homem devém animal ao mesmo tempo em que o animal devém... (mas devém o quê? humano, ou outra coisa?)".147
[142] DG. Kafka - pour une littérature mineure. Paris: Minuit, 1975.

[143] Le totémisme aujourd'hui. Paris: PUF, 1962, e La pensée sauvage. Paris: Plon, 1962.

[144] Recorde-se, no entanto, que, além da importância que LéviStrauss ("La structure des mythes", 1958, e La potière jalouse, 1985) atribui à "fórmula canônica do mito" - cifra misteriosa, intensiva e metamórfica (morfodinâmica: J. Petitot, "Approche morphodynamique de la formule canonique du mythe". L'Homme, 106107, pp. 24-50, 1988) —, o fundador do estruturalismo antropológico é o primeiro a reconhecer as limitações do vocabulário da lógica extensional para dar conta das transformações que ocorrem em/entre os mitos (p.ex. L.-Strauss. "L'homme nu". Mythologiques IV. Paris: Plon,. 1971, pp.567-8; Histoire de Lynx. Paris: Plon, 1991, p. 249). Ademais, se é possível dizer que as Estruturas elementares tratam de objetos que se parecem com, justamente, estruturas, as análises míticas consolidadas nas Mitológicas - nas quais Lévi-Strauss desenvolve toda uma "teoria dos códigos primitivos" ( $A E$, p. 219) - e nos livros subseqüentes parecem-se muitíssimo mais com mapas rizomáticos do que com decalques estruturais. As relações que constituem as narrativas ameríndias, antes que formando totalidades combinatórias em distribuição lógica discreta, em variação concomitante e tensão dialética com os realia socioetnográficos, instanciam a um ponto que se poderia dizer de exemplaridade os princípios rizomáticos de "conexão e heterogeneidade", "multiplicidade", "ruptura assignificante" e "cartografia" que Deleuze e Guattari contrapõem aos modelos estruturais ( $M P$, pp. 13-21). Creio que é preciso examinar de mais perto essa afinidade entre o estruturalismo lévistraussiano tardio e a analítica diferencial deleuziana (em P. Maniglier. La vie énigmatiques des signes. Saussure et la naissance du structuralisme, encontram-se alguns elementos essenciais para tanto).

[145] M. DeLanda. Intensive science and virtual philosophy, p. 75 .

[146] MP,p.305.

[147] Idem, p. 290 
[148] Idem, p. 292.

[149] M. DeLanda. "100o Years of War: CTheory interview with Manuel DeLanda (with D. Ihde, C. B. Jensen, J. J. Jorgensen, S. Mallavarapu, E. Mendieta, J. Mix, J. Protevi, E. Selinger)". CTheory, a127. 〈http://www.ctheory.net/articles.aspx? $\mathrm{id}=383>$, 2003, p. 15.

[150] MP,pp. 294, 296.

[151] Idem, pp. 295-6.

[152] Idem.

[153] Idem, p.36.

[154] Idem, p. 291.
Devir, prosseguem os autores, é um verbo com uma consistência toda sua; ele não é imitar, aparecer, ser, corresponder. E - surpresa "devir [...] tampouco é produzir, produzir uma filiação ou produzir mediante uma filiação" ${ }^{148}$. Nem filiação, nem produção. Não estamos mais no Anti-Édipo.

"O pensamento intensivo em geral é um pensamento sobre a produção", afirma DeLanda ${ }^{149}$. Penso que talvez as coisas sejam mais complicadas que isso. O conceito de devir desempenha efetivamente o mesmo papel "cosmológico" axial em Mil platôs que o conceito de produção no Anti-Édipo. Não porque "tudo é devir" - isto seria um solecismo - , nem porque não haja outras noções importantes no livro (máquina de guerra, segmentaridade, ritornelo, regime de signos, rostidade, agenciamento: não faltam exemplos), mas porque o conceito anti-representativo por excelência do Mil platôs, no sentido de ser o dispositivo que bloqueia o trabalho da representação, éo conceito de devir, exatamente como a produção era o dispositivo anti-representativo do Anti-Édipo. Produção e devir: dois movimentos distintos, cuja relação seria preciso determinar. Ambos envolvem a natureza, ambos são intensivos e pré-representativos; em certo sentido, eles são dois nomes de um só movimento: o devir é o processo do desejo, o desejo é a produção do real, o devir e a multiplicidade são uma coisa só, o devir é um rizoma, e o rizoma é o processo de produção do inconsciente. Mas em outro sentido - "sentido" também no sentido de direção - eles não são, definitivamente, o mesmo movimento: entre a produção e o devir, o trajeto não éo mesmo nos dois sentidos. A produçãoé um processo no qual se realiza a identidade do homeme da natureza, em que a natureza se revela ela própria como processo de produção ("a essência humana da natureza e a essência natural do homem seidentificam na natureza como produção ou indústria..." - D.G.1972: 10). Devir, contudo, é uma participação anti-natural (contre nature) entre o homem e a natureza, movimento instantâneo, não-processivo, de captura, de simbiose, uma conexão transversal entre heterogêneos ${ }^{150}$. "[A] natureza só procede assim, contra si mesma. Estamos longe da produção filiativa ou da reprodução hereditária..." ${ }^{151}$. O devir é anti-produtivo, ou contraproducente.

"O Universo não funciona por filiação"152. Difícil ser mais explícito.O universo, note-se, em todos os seus estados, o intensivo-virtual como o extensivo-atual. Ora, se ele não funciona por filiação (antes que não por outra coisa qualquer), é-se tentado a concluir que ele funciona por aliança. Efetivamente, já no primeiro platô lia-se que "a árvore é filiação, mas o rizoma é aliança, é unicamente de aliança”" 153 . E agora lê-se que "O devir não é uma evolução, pelo menos não uma evolução por descendência e filiação. O devir não produz nada por filiação; toda filiação é imaginária. O devir é sempre de outra ordem que a ordem da filiação. Ele pertence à aliança". ${ }^{154}$ 
O que aconteceu, entre a análise que afirmava a filiação intensiva, ambígua, noturna do mito Dogon no Anti-Édipo e a recusa a atribuir qualquer papel significativo a esse princípio relacional no Mil platôs? Como a filiação passou de intensiva a imaginária?

Penso que a mudança reflete um deslocamento crucial do interesse analítico de Deleuze e Guattari, de um horizonte intra-específico para um inter-específico; de uma economia humana do desejo - desejo histórico-mundial, racial, sociopolítico, e não desejo familial, personológico, edipiano; mas desejo assim mesmo humano - para uma economia de afetos transespecíficos que ignoram a ordem natural das espécies e suas sínteses limitativas, conectando-nos por disjunção inclusiva com o plano de imanência. Do ponto de vista da economia do desejo do Anti-Édipo, a aliança extensiva vinha limitar a filiação intensiva e molecular, atualizando-a sob a forma molar do grupo de descendência; mas do ponto de vista da economia cósmica do afeto (do desejo como força inumana), é a filiação que vem agora limitar, com suas identificações imaginárias, uma aliança tanto mais real quanto mais contra-natural entre seres radicalmente heterogêneos: "Se a evolução comporta algum autêntico devir, é no vasto domínio das simbioses, que envolve seres de escalas e reinos totalmente diferentes, sem nenhuma filiação possível entre si [...]". ${ }^{155}$

Segue-se o exemplo favorito da vespa e da orquídea, um agenciamento "do qual nenhuma vespa-orquídea jamais nascerá" - e sem o qual, acrescente-se, nenhuma vespa e nenhuma orquídea, tais como as conhecemos, jamais poderia nascer, porque a filiação natural dentro de cada espécie depende dessa aliança contra-natureza entre as espécies.

A desterritorialização da sexualidade iniciada no Anti-Édipo se completa; a organização binária dos sexos, bissexualidade inclusive (cf.o "átomo de gênero") cede o passo a n sexos que se conectam com nespécies no plano molecular: "a sexualidade passa pelo devir-mulher do homem e o devir-animal do humano: emissão de partículas". ${ }^{156} \mathrm{E}$ se todo animal implicado em um devir-animal é uma multiplicidade molecular ("todo animal é fundamentalmente um bando, uma matilha"157), é porque ele define uma socialidade múltipla, lateral, radicalmente extra-filiativa e extra-reprodutiva que arrasta a socialidade humana em uma demoníaca metonímia universal: "Nós opomos a epidemia à filiação, o contágio à hereditariedade, o povoamento por contágio à reprodução sexuada, à produção sexual... As participações e núpcias contra-natureza são a verdadeira Natureza que atravessa todos os reinos da natureza". ${ }^{158}$

Aliança, então. Mas, outra vez, não uma aliança qualquer. Como vimos, o primeiro volume de Capitalismo e esquizofrenia postulava duas filiações, uma intensiva e germinal, a outra extensiva e somática, esta
[155] MP, p. 291; grifo no original.

[156] Idem, p.341; grifos suprimidos. Os "n sexos" seriam, a rigor, "n-1 sexos" - a unidade representada pelo sexo masculino devendo ser subtraída para que a sexualidade possa atingir o estado de multiplicidade -, assim como as n espécies dos deviresanimais são na verdade n-1 espécies (1 $=$ H. sapiens).

[157] Idem, p. 293.

[158] Idem, p. 295 
[159] O incesto (ou o que é a mesma coisa, sua proibição), por sua vez, é apenas o efeito retroativo da aliança recalcante sobre a filiação germinal recalcada (AE, pp. 193-5).
[160] GD. Critique et clinique. Paris: Minuit, 1993, p. 100.

[161] $\operatorname{Ver} A E$, p. 131.

[162] Contra-social na medida, dirse-ia, em que a socialidade humana é necessariamente contra-intensiva, uma vez que gerada como extensivização da "energia primária da ordem intensiva". contraposta pela (e à) aliança, princípio extensivo que desempenha o papel de "representação recalcante" do representante do desejo, o influxo germinal.159 Agora, no Mil platôs, vemos surgir duas alianças: aquela discutida no Anti-Édipo, interna ao socius e mesmo ao gênero masculino (homossexualidade primária, coletiva); e uma outra, imanente ao devir, irredutível tanto à produção e metamorfose imaginárias (genealogia mítica, filiação ao animal) como à troca e à classificação simbólicas (aliança exogâmica, totemismo).

Todo devir é uma aliança. O que não quer dizer, repita-se, que toda aliança seja um devir. Há a aliança extensiva, cultural e sociopolítica, e há a aliança intensiva, anti-natural e cosmopolítica. Se a primeira distingue filiações, a segunda confunde espécies, ou melhor, contra-efetua por síntese implicativa as diferenças contínuas que são atualizadas, no outro sentido (o caminho não é o mesmo nos dois sentidos), pela síntese limitativa da especiação descontínua. Quando um xamã ativa um devir-onça, ele não "produz" uma onça, tampouco se "filia" à descendência dos jaguares. Ele faz uma aliança:

Dir-se-ia maisbem que umazona de indistinção, de indiscernibilidade, de ambigüidade se estabelece entre doistermos, comose tivessematingido o ponto que precede imediatamente sua diferenciação respectiva:não uma similitude, mas um deslizamento, um avizinhamento extremo, uma contigüidade absoluta; não uma filiação natural, mas uma aliança contra-natureza. ${ }^{160}$

Uma definição de devir. Note-se que ela corta pelo meio o contraste estruturalista, molar, entre filiação, continuidade metonímica e semelhança serial, por um lado, e aliança, descontinuidade metafórica e diferença opositiva, por outro lado. A "contigüidade absoluta" de tipo tangencial-diferencial estabelecida pela aliança contra-natureza é certamente outra coisa que a "descontigüidade" absoluta entre linhagens filiativas estabelecida pela aliança simbólico-cultural (exogamia). Mas ela tampouco se resume, desnecessário acrescen$\operatorname{tar}^{161}$, a uma identificação ou indiferenciação imaginária entre os "dois termos". Não se trata portanto de opor filiação natural a aliança cultural, como nas teorias clássicas do parentesco. A contra-naturalidade da aliança intensiva é igualmente contra-cultural, e contrasocial ${ }^{162}$. Estamos falando de um terceiro incluído, uma outra relação, uma "nova aliança".

Não é preciso deixar a paisagem africana para encontrarmos essa outra aliança. Na seção "Memórias de um feiticeiro II" do $10^{\circ}$ platô, os autores evocam os homens-animais do tipo daqueles "defloradores sagrados" estudados por Pierre Gordon, ou dos hienomens de algumas tradições sudanesas descritas por G. Calame-Griaule. Esses últimos fornecem a ocasião para um comentário, a nosso ver, decisivo: 
[O] homem-hiena viva nas margens da aldeia, ou entre duas aldeias, de modo que pode vigiar nas duas direções. Um herói, ou mesmo dois heróis, cada qual com uma noiva na aldeia do outro, vencerão o homem-animal. É como se fosse necessário distinguir entre dois estados muito diferentes da aliança: uma aliança demoníaca que se impõe do exterior, e que impõe sua lei a todas as filiações (aliança forçada com o monstro, com o homem-animal); e uma aliança consentida, que se conforma ao contrário à lei das filiações, e que se manifesta quando os homens das aldeias vencem o monstro e passam a organizar suas próprias relações. Tal distinção pode vir a modificar a questão do incesto. Pois não basta dizer que a proibição do incesto deriva das exigências positivas da aliança em geral. Há, ao contrário, uma forma de aliança que é tão estranha, tão hostil à filiação, que ela assume necessariamente o valorde incesto (o homem-animal sempre tem uma relação com o incesto). A segunda forma de aliança proíbe o incesto porque só pode se submeter aos direitos da filiação estabelecendo-se entre filiações distintas. O incesto aparece duas vezes, como potência monstruosa da aliança quando esta subverte a filiação, mas também como potência interdita da filiação quando esta submete a aliança e deve distribuí-la entre linhagens distintas. ${ }^{163}$

"Isso pode vir a modificar a questão do incesto": os autores parecem estar se referindo à teoria das Estruturas elementares; mas cuido que a observação se aplica igualmente bem ao modo como a questão era tratada no Anti-Édipo. Pois agora é a noção de aliança que passa a ter uma dupla incidência; não é apenas uma reguladora da "sexualidade enquanto processo de filiação", mas também "uma potência de aliança a inspirar uniões ilícitas e amores abomináveis". Seu propósito não é o de gerir, mas o de "impedir a procriação": aliança antifiliativa ${ }^{164}$. Mesmo aquela aliança échangiste, recalcante, produtora de filiação, começa aqui a mostrar certos poderes ocultos - como se tivesse sido contaminada pela outra aliança, a aliança intensa e demoníaca. "É verdade que a aliança e a filiação estão em relações reguladas pelas leis de casamento, mas mesmo ali a aliança retém uma potência perigosa e contagiosa. Como Leach demonstrou [...]"165. É interessante notar como a palavra "potência", puissance, passa insistentemente a qualificare determinar a aliança, neste passo do Mil platôs. O conceito de aliança cessa de designar uma instituição - uma estrutura - e se torna uma potência, um potential — um devir. Da aliança como forma à aliança como força, passando ao largo da filiação como substância. Não estamos aqui no elemento místicoserial do sacrifício nem no elemento mítico-estrutural do totemismo, mas no elemento mágico-real do devir. ${ }^{166}$

Não estamos tampouco no elemento do Contrato Social. "O desejo ignora a troca; ele só sabe do roubo e do dom"167. Mas, nova-
[163] MP, p.303 [n.15].

[164] Idem, p.301.

[165] A referência é a "Rethinking anthropology" (In:Rethinking anthropology. Londres: Athlone, 1961, p. 20), em que E. R. Leach observa a generalidade de uma noção de "influência metafísica" que se exerceria entre aliados por casamento.

[166] M. Goldman. "Formas do saber e modos do ser: observações sobre multiplicidade e ontologia no candomblé". Religião e Sociedade, 25 (2), 2005, e E. Viveiros de Castro. "The gift and the given: three nanoessays on kinship and magic". In: S. Bamford e J. Leach (orgs.). Genealogy beyond kinship: sequence, transmission, and essence in ethnography and social theory. Oxford: Berghahn Books, 2007 (no prelo).

[167] $A E$, p. 219; grifos no original. 
[168] Sobre troca e perspectiva, ver M. Strathern. The gender of the gift:problems with women and problems with society in Melanesia, pp. 230, 271, 327; idem, Partial connections, passim idem, After nature: English kinship in the late twentieth century, pp. 96-100; idem, Property, substance and effect: anthropological essays on persons and things, 1999,pp.249-56; N.Munn. The fame of Gawa: a symbolic study of value transformation in a Massim (Papua New Guinea) society. Durham: Duke University Press,1986, p. 16; C. Gregory. Gifts and commodities. Londres:Academic Press, 1982, p.19. Sobre a noção de dupla captura, ver G. Deleuze e C. Parnet. Dialogues. Paris: Flammarion 1996, pp.7-9; I. Stengers. Cosmopolitiques, tome1. La guerre des sciences. Paris: La Découverte/Les Empêcheurs de Penser en Rond, 1996:, pp. 64, n. 11.

[169] "A linguagem pode trabalhar contra aquele que a usa.[...] A noção de socialidade é freqüentemente entendida como se implicasse sociabilidade, a reciprocidade, como se significasse altruísmo, e o fato da relação, solidariedade [...]" (M. Strathern. Property, substance and effect: anthropological essays on persons and things, 1999, p.18). A propósito, "ação sobre uma ação" é a definição(nietzschiana) de poder para Foucault; "reação a uma reação" é uma das definições propostas por Bateson para seu conceito de "cismogênese". Quanto ao roubo queé a vida, essa é de A. N. Whitehead: "A vida é roubo, e o ladrão requer uma justificativa" (apud I. Stengers. Penser avec Whitehead. Paris: Seuil, p. 349). A outra todos sabem de quemé.

[170] E. Viveiros de Castro. "GUT feelings about Amazonia: potential affinity and the construction of sociality". In: L. Rival e N. Whitehead (orgs.).Beyond the visible and the material: the amerindianization of society in the work of Peter Rivière. Oxford: Oxford University Press, 2001; "O problema da afinidade na Amazônia". In: $A$ inconstância da alma selvagem e outros ensaios de antropologia. São Paulo: Cosac Naify, 2002; “The gift and the given: three nano-essays on kinship and magic", 2007 mente, há troca e troca. Há uma troca que certamente não é "échangiste" no sentido capitalista-mercantil do termo, já que pertence à categoria do roubo e do dom: a troca característica das "economias do dom", precisamente - a aliança estabelecida pela troca de dons, movimento alternado perpétuo de dupla captura, onde os parceiros comutam (contra-alienam) perspectivas invisíveis mediante a circulação de coisas visíveis (suas "possessões inalienáveis") ${ }^{168}$. Os dons podem ser recíprocos; mas isso não faz de sua troca um movimento menos violento; todo o propósito do ato de donação é forçar o parceiro a agir, extrair um gesto do outro, provocar uma resposta: roubar sua alma. (A aliança como roubo recíproco de alma.) E, neste sentido, não há ação social que não seja uma troca de "dons", pois toda ação é "social" enquanto, e apenas enquanto, é ação sobre uma ação, reação a uma reação. Reciprocidade, nesse caso, significa apenas recursividade. Nenhuma insinuação de sociabilidade; menos ainda, de altruísmo. A vida é roubo. Só me interessa o que não é meu. ${ }^{169}$

\section{CONCLUSÃo, PRECEDIDA dE UMA BREVE EVOCAÇÃo AMAZÔNICA}

"Aliança" é uma boa e uma má palavra. Toda palavra é boa se pode ser usada para cruzar a fronteira entre pessoas e coisas. Assim, aliança é uma boa palavrase vocêa usarpara um micróbio. Forçaéuma boa palavra se você a usarpara um humano.

Bruno Latour, 1993.

A distinção entre as duas alianças proposta noMil platôs parece se impor com a força de um "traço típico", etnologicamente falando, quando deixamos a paisagem do Oeste da África pela da Amazônia indígena. Ela corresponde de perto a um contraste reconhecido pelos etnógrafos dessa última região entre uma afinidade intensiva ou "potencial", cosmológica, mítico-ritual, da qual se poderia perfeitamente dizer que é "ambígua, disjuntiva, noturna e demoníaca", e uma afinidade extensiva ou "efetiva", subordinada à consangüinidade. Como já tratei desse tema em diversos estudos sobre o parentesco amazônico ${ }^{170}$, não me arrisco aqui a ser mais que sumariamente alusivo.

Em geral, nas sociedades amazônicas, a afinidade matrimonial é concebida como uma relação profundamente delicada, em todos os sentidos do adjetivo: perigosa, frágil, incômoda, embaraçosa e preciosa ao mesmo tempo, ela é moralmente densa, afetivamente ambivalente, politicamente estratégica, economicamente fundamental. Conseqüentemente, os laços de afinidade são o foco de um esforço sistemático de invisibilização, realizado, o mais das vezes, através de seu mascaramento ou neutralização pelas relações de consangüini- 
dade (germanidadee filiação). ${ }^{171}$ Os afins terminológicos (relações de afinidade a priori, características dos chamados sistemas elementares de parentesco) são vistos como tipos de cognatos (primos e tios cruzados); os afins efetivos são consangüinizados na referência e no tratamento; os termos específicos de afinidade são evitados em favor de seus equivalentes consangüíneos ou de tecnônimos que exprimem a co-consangüinidade; os cônjuges são ditos se tornarem consubstanciais por via do sexo e da comensalidade cotidiana, e assim por diante. Como observou Peter Riviére ${ }^{172}$ para o caso bastante típico das Guianas, "dentro da aldeia ideal a afinidade não existe". Mas se ela não existe ali, haverá de existir alhures. Dentro da aldeia real, para começar; mas sobretudo fora da aldeia ideal: no exterior ideal da aldeia, enquanto afinidade "ideal", ou intensiva. Assim que deixamos a aldeia, real ou ideal, o mascaramento se inverte, e a afinidade se torna a forma genérica da relação social, tanto mais forte quanto mais genérica, tanto mais explícita quanto menos substancial: o cunhado perfeito é aquele com cuja irmã não casei, ou que não casou com minha irmã. Era o cativo tupinambá, por exemplo, inimigo-cunhado (o termo era um só: tovajara) votado à morte cerimonial em terreiro. Os afins são inimigos, e assim, os inimigos são afins. Quando os afins não são inimigos, quando são parentes e co-residentes - o caso "ideal" - então é preciso que não sejam tratados como afins; quando os inimigos não são afins, é porque são inimigos, isto é, devem ser tratados como afins. ${ }^{173}$

As variadas relações supra-locais na Amazônia tendem assim a ser fortemente conotadas pela afinidade: alianças localmente exogâmicas, raras mas politicamente estratégicas; laços ritualizados de amizade ou parceria comercial; cerimonialidade intercomunitária; um estado permanente de "guerra", física ou espiritual, latente ou manifesta, entre os grupos locais. Tal afinidade intensiva atravessa as fronteiras entre as espécies: animais, plantas, espíritos, todos se acham implicados em tais relações sintético-disjuntivas com os humanos. Até segunda ordem, e o mais das vezes até o fim, são todos afins.

Essa relação de afinidade virtual pura, o esquematismo genérico da alteridade na Amazônia, pertence indubitavelmente ao "segundo tipo de aliança" mencionado no Mil platôs. Ela é hostil à filiação, uma vez que surge sobretudo ali onde o casamento não é uma opção (ou, pelo menos, uma preferência), e sua produtividade não é do tipo procreativo; ela é, antes, parte de uma máquina de guerra anterior e exterior ao parentesco enquanto tal. Uma aliança contra a filiação: não no sentido de ser a representação recalcante de uma filiação intensiva primordial, mas porque impede a filiação de funcionar como germe de uma transcendência (a origem mítica, o ancestral fundador, o grupo de filiação identitário). Toda filiação é imaginária, dizem os
[171] A evitação do nome ou da pessoa do afim, sinal de um respeito hiperbólico para com ele, é o outro modo usual de lidar com a delicadeza da afinidade. Forma alternativa de invibilização, então; pois o respeito exagerado faz do afim menos um antiparente - o que ele, a vários títulos, é (mesmo quando não é) - que um super-parente.

[172] Individual and society in Guiana: a comparative study of Amerindian social organization. Cambridge: Cambridge University Press, 1984, p. 70.

[173] O problema liminar colocado por qualquer tentativa de imaginar um equivalente indígena para nossa "filosofia" é o de pensar um mundo constituído pelo ponto de vista do Inimigo (E.Viveiros de Castro.From the enemy's point of view. Humanity and divinity in an Amazonian society. Chicago: University of Chicago Press, 1992) como determinação transcendental. Um mundo onde a "inimizade" não é um mero complemento privativo da Amizade, nem uma simples facticidade negativa, mas uma estrutura de direito do pensamento, uma positividade, que define uma outra relação com o saber, e um outro regime regime de verdade ("Do canibalismo como estrutura epistemológica".) 
[174] P. Clastres. "Archéologie de la violence: la guerre dans les sociétes primitives". Libre, 1, pp. 137-73, 1977.

[175] Lévi-Strauss. Histoire de Lynx, p. 295 .

[176] Idem, L'homme nu. Mythologiques $I V$, pp. 503 ess.

[177] Ver R. Wagner, Lethal speech Daribi myth as symbolic obviation. Ithaca e Londres: Cornell University Press, 1978

[178] Os mitos ameríndios, naturalmente, também contêm motivos "edipianos", figuras paternas, conflitos entre pais e filhos. Lévi-Strauss aludiu mesmo, não sem ironia, a um "Totem e tabu jívaro" (La potière jalouse, cap. XVI). Mas é bastante claro que, para ele, a mitologia do continente, em particular aquela que trata da origem da cultura, gira em torno da afinidade e da troca, não da parentalidade e da procriação. autores do Mil platôs. Eu acrescentaria: e toda filiação projeta um Estado, é filiação de Estado. A aliança intensiva amazônica é uma aliança contra o Estado. ${ }^{174}$

A afinidade intensiva ou primordial é, no meu entender, um dos signos mais característicos da socialidade amazônica, talvez da América indígena como um todo; não é impossível que estejamos aqui tocando a "rocha-mãe" 175 da cosmologia ameríndia enquanto macroobjeto historicamente coerente. Considere-se o complexo continental percorrido pelas Mitológicas, cujo tema é origem da cultura humana. Se compararmos os mitos ameríndios com nossa própria mitologia da cultura, uma diferença que ressalta é a dominância das relações de afinidade nos primeiros e das relações de parentalidade na segunda. As figuras centrais dos mitos ameríndios estão canonicamente relacionadas como afins; um personagem conspícuo dessas narrativas, para tomarmos um exemplo, é o sogro canibal, o Mestre não-humano de todos os bens culturais, que submete seu genro a uma série de provas com intenção de matá-lo; o rapaz as supera todas (freqüentemente graças às habilidades de outros animais que se apiedam dele) e retorna ao seio da comunidade humana trazendo o precioso butim da cultura. O conteúdo deste arqui-mito ${ }^{176}$ não é muito diferente do enredo prometéico: há o céu e a terra, há um herói preso entre os dois; há o fogo civilizador, e o "dom" das mulheres, e a origem da mortalidade humana. Mas os protagonistas do mito ameríndio são sogros ou cunhados, não figuras paternas ou filiais como aquelas que reinam nas mitologias do Velho Mundo, sejam elas gregas, próximo-orientais, africanas ou freudianas. Para encurtar o argumento, digamos que no Velho Mundo os humanos tiveram de roubar o "fogo" de um pai divino, enquanto os ameríndios tiveram de furtá-lo de um sogro animal, ou recebê-lo de presente de um cunhado animal.

Pode-se dizer que a mitologiaé o discurso do Dado177. Nela se dá de uma vez por todas aquilo que doravante será tomado como dado — as condições primordiais a partir das quais, e contra as quais, os humanos se definem ou constroem; ela estabelece os termos da dívida ontológica. Se este é o caso, então a dívida ameríndia não concerne a filiação e a parentalidade, mas a casamento e a afinidade; o Outro, como vimos, é primeiro de tudo um afim. Note-se que não me refiro aqui ao fato trivial de que os mitos indígenas tratam as relações de afinidade como sempre "já lá" - eles fazem o mesmo com as relações consangüíneas, ou imaginam mundos em que os pré-humanos ignoravam as proibições matrimoniais etc. ${ }^{178}-$, mas ao fato de que a afinidade constitui a moldura, a armação sociológica dentro da qual se transmite a mensagem do mito. Essa moldura contém uma variedade de espécies degente. Em particular, ela é repleta de afins animais.É imperativo que eles sejam animais, ou, mais geralmente, não-humanos (futuros não- 
humanos, isto é, no mito todo mundo é parcialmente humano, os humanos atuais inclusive, embora o caminho não seja o mesmo nas duas direções).

É esta aliança como não-humano que define "as condições intensivas do sistema" naAmazônia.

Mas nesse plano não pode haver, estritamente falando, uma distinção - necessariamente extensiva - entre aliança e filiação. Ou por outra, se há duas alianças, há também duas filiações. Se toda produção é filiativa, nem toda filiação é (re)produtiva; se há filiações reprodutivas e administrativas (representativas, de Estado), há também filiações contagiosas e monstruosas, aquelas que resultam de alianças e devires contra-natureza. Eis por que o incesto possui uma "afinidade" intrínseca com as uniões trans-específicas: a hiper-exogamia e a hiperendogamia vertem uma na outra no mundo intensivo do mito, o mundo da diferença fluente que condiciona e acompanha o mundo atual como sua contraparte virtual. ${ }^{179}$

O conceito amazônico de afinidade potencial constitui-se, do ponto de vista de seu quadro teórico de referência, em ruptura com a imagem "troquista" do socius. (Donde a importância da noção de "predação ontológica" - o roubo e o dom - que lhe está associada $^{180}$ ) Ele procurava captar o movimento de uma outra "potência da aliança" intrínseca às socialidades indígenas, potência cosmopolítica irredutível à afinidade doméstico-pública (ah, a esfera pública...) das teorias clássicas do parentesco, fossem elas estrutural-funcionalistas, estruturalistas ou marxistas. Por outras palavras, o tema amazonista da afinidade potencial pressupôs desde o começo a conceitualidade desenvolvida em Capitalismo e esquizofrenia. Ele "jamais foi (inteiramente) lévi-straussiano". O roubo, o dom, o contágio, o dispêndio e o devir: é dessa troca que se trata. Uma outra potência da aliança - a aliança potencial.

No último quartel do século passado, a chamada teoria estruturalista da aliança de casamento, que dominara a cena nos anos 1960 , veio a conhecer um crescente desfavor crítico. OAnti-Édipo foi um elemento decisivo nesse deslocamento, na medida em que exprimiu em uma linguagem particularmente vigorosa e eficaz a recusa intransigente de toda concepção "troquista" do socius. Mas, se é inegável que essa atitude persiste em Mil platôs, os termos do problema mudam ligeiramente, ali. No Anti-Édipo, a troca era afastada em favor da produção enquanto modelo geral da ação, e a circulação (à qual Deleuze e Guattari assimilavam unilateralmente a troca no sentido de Mauss) se subordinava à inscrição. ${ }^{181}$ No Mil platôs, como vimos, a produção abre
[179] Há mitologias amazônicas que projetam um cenário cósmico, ou, antes, pré-cósmico, bastante similar à situação de "filiação intensiva" discernida por Deleuze e Guattari no mito dos Dogon. Os mitos do povos Tukano e Aruaque do noroeste amazônico, em particular, devem ser mencionados (S. Hugh-Jones. The palm and the pleiades. Initiation and cosmology in North-West Amazonia. Cambridge: Cambridge University Press, 1979; "Clear descent or ambiguous houses? A re-examination of Tukanoan social organization". L'Homme, 126-8, pp. 95-120, 1993), ainda que, como argumenta G. Andrello (Cidade do índio. Transformações e cotidiano em Iauaretê. São Paulo: Edunesp/ISA/NuTI, 2006), eles pertençam ao mesmo metaesquema de afinidade intensiva que constitui o estado basal - o plano de imanência - do pré-cosmos amazônico. A questão, contas feitas, parece-me menos a de saber se há uma ou duas alianças, ou uma ou duas filiações, ou se os mitos amazônicos reconhecem ou não uma filiação primordial etc., que a de determinar de onde provém a intensidade. A questão é a de saber, enfim, se o exterior nasce do interior (se a aliança descende da filiação) ou o contrário, se o interior é a repetição do exterior.

[180] E. Viveiros de Castro, "O problema da afinidade na Amazônia".

[181] OAnti-Édipo repete o clichêhistórico-materialista dos anos 1970 sobre uma suposta "redução da reprodução socialà esfera da circulação" que oneraria a etnologia de corte maussiano e estruturalista ( $A E$, p. 222). 
[182] $A E$, pp.33 ess.

[183] GD. "CoursVincennes 28/5/73". In: http://www.webdeleuze.com).Ver J. Donzelot. "An anti-sociology", F. Lyotard. "Energumen capitalism". Semiotext(e), II(3), pp. 11-26, 1977, e F. Zourabichvili.Le vocabulaire de Deleuze, pp. 48-51, para avaliações da relação de Anti-Édipo e de Mil platôs com a conceitualidade marxista.

[184] F. Lyotard, op.cit., p.15. espaço para um outra relação não-representativa, o devir. Se a produção é inerentemente filiativa, o devir mostra uma afinidade com a aliança. O que se passa então com a posição anti-troquista, quando se passa da produção ao devir?

É sabido, ainda que muitas vezes convenientemente esquecido, que a produção do Anti-Édipo não é exatamente idêntica ao conceito marxista homônimo. A "produção desejante" de Deleuze e Guattari não deve ser confundida com a "produção necessitada" hegelianomarxista, dominada pelas noções de falta e de necessidade ${ }^{182}$. A diferença é várias vezes sublinhada: "nosso problema nunca foi o de uma volta a Marx; eleé muito mais o de um esquecimento, o esquecimento de Marx inclusive. Mas, no esquecimento, pequenos fragmentos sobrenadam $[\ldots]]^{183}$. Acrescente-se que a produção desejante fluente do Anti-Édipo distingue-se mal de um processo de circulação generalizada; como Lyotard provocativamente sugeriu, "esta configuração do Kapital, a circulação de fluxos, se impõe pela predominância do ponto de vista da circulação sobre o da produção". ${ }^{184}$

A concepção finitiva e necessitarista de produção tem ampla liquidez nos círculos antropológicos; é em seu nome e de seus acessórios - dominação, falsa consciência, ideologia — que as posições "troquistas" são, via de regra, criticadas dentro da antropologia. Mas seé desejável, e mesmo necessário, fazer essa distinção entre a produção necessitada da economia política e a produção desejante da economia maquínica, a produção-trabalho e a produção-funcionamento, pode-se argumentar por analogia que seria igualmente interessante distinguirmos entre uma aliança-estrutura e uma aliança-devir, uma troca-contrato e uma troca-metamorfose. Essa distinção permitiria isolar e descartar a concepção contratualista da aliança, ao jogar com a homonímia deliberadamente equívoca entre a aliança intensiva das sociocosmologias amazônicas (por exemplo)e a aliança entensiva das teorias clássicas, estruturalismo inclusive, do parentesco. Naturalmente, em ambos os casos a homonímia é um pouco mais que isso, visto que há uma filiação, mesmo se monstruosa antes que reprodutiva, entre os conceitos respectivos. A produção do Anti-Édipo deve muito à produção da economia política, ainda que a subverta. Semelhantemente, a aliança potencial amazônica existe em filigrana ou em contra-luz — por assim dizer, virtualmente - na obra lévi-straussiana, cujo potencial anti-edipiano, e assim (auto-)subversivo, precisa ser trazido à superfície.

O problemaé,em última análise, o de se imaginar - construir um conceito não-contratualista $e$ não-dialético de troca: nem interesse racional, nem síntese a priori do dom; nem teleologia inconsciente, nem trabalho do significante; nem fitness inclusiva, nem desejo do desejo do Outro; nem contrato, nem conflito - mas um 
modo de devir-outro ${ }^{185}$. A aliança é o modo de devir-outro próprio ao parentesco.

A lateralidade maquínica e rizomática da aliança está finalmente muito mais próxima da filosofia deleuziana que a verticalidade orgânica e arborescente da filiação. O desafio, então, é o de se liberar a aliança do controle gerencial da (e pela) filiação, liberando assim suas potências "monstruosas", isto é, criativas. No que concerne à noção gêmea da noção de aliança, a noção de troca, penso que hoje está claro que ela jamais foi realmente posta como o outro da produção, não obstante o dogma corrente. Ao contrário, a troca sempre foi tratada pela antropologia como a forma mais eminente de produção: produção da Sociedade, justamente. A questão portanto não é a de revelar a verdade nua da produção por debaixo do véu hipócrita da troca e da reciprocidade, mas, antes, a de libertar estes conceitos de suas funções equívocas dentro da máquina da produção filiativa e subjetivante, devolvendo-as a seu elemento (contra)natural, o elemento do devir. A troca, ou a circulação infinita de perspectivas - troca de troca, metamorfose de metamorfose, ponto de vista sobre ponto de vista, isto é: devir.

EduARdo Viveiros de CASTro é professor no Programa de Pós-Graduação em Antropologia Social do Museu Nacional/UFRJ e autor de A inconstância da alma selvagem (Cosacnaify, 2002).
[185] Se a expressão 'diferença de intensidade' é uma tautologia (GD. Différence et repétition, p. 287), então "devir-outro" é uma outra, ou talvez a mesma, tautologia.

Recebido para publicação

em 15 de março de 2007.

NOVOS ESTUDOS

CEBRAP

77 , março 2007

pp. $91-126$ 